\title{
RADICALES CONTRA CARLISTAS: LA LUCHA POR EL ESPACIO PÚBLICO EN CUENCA DURANTE EL SEXENIO DEMOCRÁTICO (1868-1874) ${ }^{1}$
}

\section{RADICALS AGAINST CARLISTS: THE STRUGGLE FOR PUBLIC SPACE IN CUENCA DURING THE DEMOCRATIC "SEXENIO" (1868-1874)}

\author{
Eduardo Higueras Castañeda \\ Universidad de Castilla-La Mancha
}

\begin{abstract}
SUMARIO: I. INTRODUCCIÓN.- II. SIGNOS DE POLITIZACIÓN EN UNA CAPITAL “DE TERCER ORDEN”.-III. LA DIFÍCIL CONSOLIDACIÓN DE LAS FIESTAS REVOLUCIONARIAS.- IV. LOS RADICALES EN LA CALLE: DE AMADEO I A LA REPÚBLICA.-V. LA MOVILIZACIÓN CATÓLICA: PROCESIONES Y MARGARITAS.VI. CONCLUSIONES
\end{abstract}

Resumen: El periodo abierto por la Revolución de 1868 dio lugar a un intenso proceso de politización entre la población española. Sus efectos no se limitaron a las áreas urbanas, sino que fueron también notables en el interior agrario del país. El marco democrático favoreció el debate público y la cuestión monárquica, en este sentido, se situó en el centro de las luchas políticas. El impulso secularizador que las nuevas instituciones democráticas iniciaron estuvo directamente relacionado con ese debate que demarcó, de un lado, la opción de una monarquía desacralizada y subordinada a la Constitución de 1869 y, de otro, un sector legitimista y ultracatólico, en el que la organización carlista fue determinante. Evaluar dichos procesos, desde el marco de una ciudad arquetípica de la España rural, como fue el caso de Cuenca, es el objetivo de este artículo. El análisis, en este sentido, se centra en la proyección sobre el espacio público de la movilización política.

Abstract: The Revolution of 1868 opened an historical period characterized by an intense process of politicization among the Spanish population. Its effects were not limited to urban areas, but were also important in the agrarian interior of the country. The new democratic system favored public debate. In this sense, the monarchical issue was placed at the heart of political struggles. The secularizing impulse deployed by the new democratic institutions was directly related to that debate that marked, on the one hand, the option of a de-sacralized monarchy subordinated to the Constitution of 1869 and, on the other hand, a legitimist and ultra-Catholic option, in which the influence of Carlism was decisive. The aim of this paper consists in evaluating these processes from the framework of an archetypal city of rural

\footnotetext{
1 Este artículo se enmarca en el proyecto de Investigación "Las monarquías en Europa meridional (siglos XIX y XX). Culturas y prácticas de la realeza" (HAR2016-75954-P), financiado por el Ministerio de Economía y Competitividad y con fondos FEDER; y del grupo de Investigación Seminario Permanente de Estudios Contemporáneos (UCLM).
} 
Spain, as was the case of Cuenca. The analysis, in this sense, focuses in the projection on public space of these political mobilization.

Palabras clave: España, Siglo XIX, politización, secularización, anticlericalismo, democracia, tradicionalismo

Key Words: Spain, XIX Century, politicization, secularization, anticlericalism, democracy, traditionalism

\section{INTRODUCCIÓN}

A comienzos del siglo XX, el periodista conquense Juan Giménez de Aguilar publicó una entrevista a Juan Álvaro Celada y Pedro Gómez Martínez, dos supervivientes del saqueo de Cuenca por las tropas de Alfonso de Borbón el 15 julio de 1874. Aquel episodio de la última guerra carlista se había convertido en un emblema de la pugna democrática y anticlerical ${ }^{2}$ en una ciudad que, por aquellas fechas, el novelista conquense Andrés González-Blanco bautizó de manera elocuente como "Episcópolis"3. El asalto de Cuenca, por otra parte, podría plantearse como el violento desenlace de una tensión política que, al menos desde 1869, se había desarrollado en múltiples escenarios. El conflicto entre clericalismo y anticlericalismo estuvo muy presente en una ciudad que mostró una fuerte resistencia al proceso secularizador iniciado en el Sexenio Democrático ${ }^{4}$.

No fue, por otra parte, una disputa ajena a la confrontación entre dos formas de entender la monarquia: una popular y democrática, desacralizada 5 , que

2 Herminio Lebrero Izquierdo, Lugares de Memoria Institucionalizada en Cuenca (1877-2017). La Historia que perdura, UCLM, Cuenca, 2018, pp. 61-64.

$3 \mathrm{M}^{\mathrm{a}}$ Carmen Utanda y Ángel Luis Mota (eds.), Andrés González-Blanco en Episcópolis, Diputación de Cuenca, Cuenca, 2003.

4 Sobre el impulso secularizador y la centralidad del conflicto anticlerical en el Sexenio Democrático, pueden destacarse las aportaciones de Gregorio Alonso, La nación en capilla. Ciudadanía católica y cuestión religiosa en España (1793-1874), Comares, Granada, 2014, pp. 295325; William J. Callahan, Iglesia, poder y sociedad en España, 1750-1874, Nerea, Madrid, 1984, pp. 241-267; Antonio Fernández García, "El conflicto Iglesia-Estado en la Revolución de 1868", en Estudios históricos. Homenaje a los profesores José $M^{a}$ Jover Zamora y Vicente Palacio Atard, t. II, Universidad Complutense, Madrid, 1990, pp. 441-508; Gregorio de la Fuente Monge, "El enfrentamiento entre clericales y revolucionarios en torno a 1869", Ayer, $\mathrm{n}^{\circ}$ 44, 2001, pp. 127-150; Alicia Mira Abad, Secularización y mentalidades: el Sexenio Democrático en Alicante (1868-1875), Universidad de Alicante, Alicante, 2006; Antonio Moliner Prada, "Anticlericalismo y revolución liberal (1833-1874)", en Emilio La Parra y Manuel Suárez Cortina (eds.), El anticlericalismo español contemporáneo, Biblioteca Nueva, Madrid, 1998, pp. 69-125, pp. 104-121; y Manuel Suárez Cortina, Entre cirios y garrotes. Politica y religión en la España Contemporánea, 1808-1936, UCLMUniversidad de Cantabria, Cuenca, 2014, pp. 51-59. Una perspectiva deudora del antiliberalismo militante de autores coetáneos como Eduardo María Vilarrasa y José Ildefonso Gatell en Francisco Martí Gilabert, La cuestión religiosa en la Revolución de 1868-1874, Editora Mundial, Madrid, 1989.

5 Lluís Ferran Toledano define "lo sagrado", como "aquello que no se acepta socialmente que sea puesto en juicio o ni siquiera se plantee la posibilidad de hacerlo", de modo que "en las sociedades contemporáneas no se trataria tanto de hablar de desacralización como de laicismo", en "El crucifijo y el baile. El trasvase de sacralidad entre el trono y la comunidad politica en la familia real carlista, 1868-1876", Pasado y Memoria, $\mathrm{n}^{\circ}$ 14, 2015, pp. 79-107, p. 82. En la medida en que los 
terminó ensayándose en el reinado de Amadeo I; la otra cerradamente contrarrevolucionaria $\mathrm{y}$, por ello, subordinada al catolicismo antiliberal. Esa tensión, como recordaron los dos entrevistados, era perfectamente nítida en el día a día de la población:

“-En Cuenca —nos dice Pedro Gómez Martinez- habian carlistas y liberales. Muchos eran los carlistas; pero eran muchos más los liberales. Teniamos por costumbre pasear por San Francisco, dando vueltas a una magnífica fuente de cuatro caños que alli habia. Paseaban, como es natural, carlistas y liberales. Los carlistas hacian ostentación de sus ideas llevando la simbólica margarita en el ojal..."6

La Glorieta en la que se encontraba la fuente de San Francisco constituía en esos momentos el vértice de la sociabilidad informal que transcurría fuera del espacio privado. Allí confluían las calles de Madereros y su continuación del Juego de la Pelota Viejo — “la más pública y concurrida de la población”7, según afirmaba El Eco de Cuenca- con la de las Torres. Eran las principales vías de la ciudad extramuros, donde se concentraba la mayor parte del comercio y, también, donde residía la pequeña clase media de empleados públicos, propietarios y profesionales liberales que protagonizaron la vida política local durante el Sexenio ${ }^{8}$. Ese entramado urbano de la Cuenca acomodada fue el principal escenario de las manifestaciones públicas de la lucha politica en la ciudad. La politización, sin embargo, no quedó restringida a las capas mesocráticas de la población.

El testimonio citado aporta, en este sentido, un indicio interesante de hasta qué punto se estaba verificando "el descenso de la política" a las clases menos favorecidas de la capital de una provincia rural, en el contexto de derechos y libertades abierto por la Revolución de Septiembre de 186810. En primer lugar,

progresistas radicales defendieron la necesidad de someter a vigilancia y crítica la institución monárquica y al propio monarca, podría hablarse de una "desacralización” del trono.

6 Juan Giménez de Aguilar, "Cuenca y los carlistas. Los supervivientes de la bárbara irrupción carlista relatan a los conquenses las incidencias de aquellos momentos de angustia y entereza", se conserva el recorte de este reportaje sin fecha en el Archivo Municipal de Cuenca [AMCU], Fondo Federico Muelas, leg. 1/28.

7 El Eco de Cuenca, 21-6-1871.

8 Miguel Ángel Troitiño Vinuesa, Cuenca: evolución y crisis de una vieja ciudad castellana, Ministerio de Obras Públicas y Urbanismo-Universidad Complutense, Madrid, 1984, pp. 331 y ss.

9 Sobre el concepto de politización como el descenso o aprendizaje de la política entre las masas, es imprescindible la aportación de Maurice Agulhon, La République au Village. Les populations du Var de la Révolution a la IIe République, Seuil, Paris, 1979; y las contribuciones al volumen coordinado por el mismo autor, La politisation des campagnes au XIXe Siècle. France, Italie, Espagne et Portugal, École Française de Rome, Paris, 2000; asimismo, Maurice Agulhon, Politica, imágenes, sociabilidades. De 1789 a 1989, Prensas de la Universidad de Zaragoza, Zaragoza, 2016.

10 Un balance reciente sobre el periodo en Rafael Serrano García, "Historiografía reciente en torno a la Revolución Gloriosa y el Sexenio Democrático (1868-1874)", en Diego Caro Cancela (ed.), La revolución de 1868 en Andalucia, Peripecias Libros, Cádiz, 2018, pp. 15-44; esta aproximación actualiza y complementa su anterior trabajo sobre "La historiografía en torno al Sexenio 18681874: entre el fulgor del centenario y el despliegue sobre lo local", Ayer, n 44, 2001, pp. 11-32. Puede, asimismo, destacarse la interpretación general del periodo que en Gregorio de la Fuente 
porque los entrevistados no pertenecían a esas elites acomodadas que escribian los periódicos, dirigian los comités de partido o se presentaban como candidatos a las elecciones ${ }^{11}$. Los dos mostraron su compromiso con las conquistas revolucionarias incorporándose los Voluntarios de la Libertad, la vieja milicia nacional reorganizada tras la Septembrina. Una fuerza caracterizada por el importante peso que en ella adquirieron las clases populares ${ }^{12}$. En Cuenca, al contrario de lo que ocurrió en otras ciudades, donde el arraigo del republicanismo fue notable, la milicia estuvo vinculada al Partido Progresista-Democrático o Radical ${ }^{13}$.

Al reducir la pluralidad política que existió en ciudad durante el Sexenio Democrático a "carlistas y liberales", los dos entrevistados subrayaban la fuerte polarización política que caracterizó al periodo. Los dos polos de esa tensión entre reacción y democracia, en Cuenca, fueron la Comunión Católico-Monárquica y el Partido Radical ${ }^{14}$. Ambas organizaciones desempeñaron un importante papel en la socialización politica de las clases populares ${ }^{15}$. Por otra parte, el empuje católico-monárquico estimuló el acercamiento entre los radicales y los federales. Una aproximación que, igualmente, favoreció la decantación republicana de los progresista-demócratas entre 1871 y 1873, conforme se fue deteriorando su confianza en la compatibilidad entre democracia y monarquía ${ }^{16}$. Esta tensión fue más allá de las urnas y de los periódicos. La calle se convirtió en otro espacio a conquistar mediante la ocupación y la exhibición de los símbolos que identificaban a cada imaginario politico ${ }^{17}$.

Monge y Rafael Serrano García, La revolución gloriosa. Un ensayo de regeneración nacional (18681874), Biblioteca Nueva, Madrid, 2005, pp. 9-40.

11 Juan Álvaro Celada era un zapatero de 22 años en 1873. Residía en la calle Fuensanta. No se ha logrado identificar a Pedro Gómez en AMCU, Año de 1873. Padrón general del vecindario de la Ciudad de Cuenca, leg. 919, exp. 3.

12 Juan Sisinio Pérez Garzón, Milicia Nacional y revolución burguesa. El prototipo madrileño, 1808-1874, CSIC, Madrid, 1978, pp. 507-517.

13 Sinesio Barquín Armero, Los Voluntarios de la Libertad en la Ciudad de Cuenca (1868-1874). La Milicia ciudadana como garante del poder revolucionario, Trabajo de Máster, UNED, 2012.

14 Eduardo Higueras Castañeda, "Radicales y federales: el ejemplo de Cuenca en el proceso democratizador de 1868-1873", Hispania Nova, n 12, 2014.

15 Debe subrayarse el proceso de modernización que el carlismo experimentó para adaptarse y sacar rendimiento del nuevo contexto político "dejando a un lado la opción armada mientras la vía democrática le pareció beneficiosa", Alexandre Dupont, "Una politización paradójica: carlismo, democracia e implicación popular durante el Sexenio Democrático", Investigaciones Históricas, $\mathrm{n}^{\circ}$ 37, 2017, pp. 40-68, p. 62. Ofrecen argumentos sobre la modernización de la cultura carlista Lluís Ferran Toledano, Entre el sermó i el trabuc: el carlisme català contra la revolució setembrina (1868-1872), Pagès, Lleida, 2001; Jordi Canal, El carlismo. Dos siglos de contrarrevolución en España, Alianza, Madrid, 2000, p. 167; y Julio Aróstegui, Jordi Canal, Eduardo González Calleja, Las guerras carlistas: hechos, hombres e ideas, La Esfera de los Libros, Madrid, 2003, pp. 79-80.

16 Sobre la evolución de los radicales hacia el republicanismo, Eduardo Higueras Castañeda, Con los Borbones, jamás. Biografia de Manuel Ruiz Zorrilla (1833-1895), Marcial Pons, Madrid, 2016, pp. 237 y ss.

17 Al respecto: Sergio Sánchez Collantes, "Luchas simbólicas por el espacio público en el Sexenio Democrático: republicanos y monárquicos en las calles españolas, 1868-1874", Crisol, $\mathrm{n}^{\circ}$ 5, 2019, pp. 203-219. 
Es habitual señalar el momento inmediatamente posterior al cambio de régimen como el de mayor efervescencia politica y protagonismo popular ${ }^{18}$. La "fiesta revolucionaria" permitió la eclosión de nuevos símbolos, así como la destrucción de aquellos que identificaban al régimen caído ${ }^{19}$. En el caso de Cuenca, apenas existen datos para contrastar tal efervescencia. El pronunciamiento no se realizó ante la población reunida en masa en las plazas, ni mucho menos con su participación, sino a puerta cerrada, con "un considerable número de personas de todas clases y posiciones que concurrieron en cuanto lo permitia el local" del Ayuntamiento ${ }^{20}$. No hay rastro de manifestaciones ni aglomeraciones en la documentación conservada, que tampoco ofrece ejemplos de violencia simbólica contra las imágenes de Isabel II o los emblemas monárquicos. La Junta revolucionaria, por otra parte, no mostró gran interés en renombrar las calles de la ciudad para conmemorar el nuevo contexto político ${ }^{21}$.

Cuenca, por el contrario, fue un caso arquetípico de la "revolución tranquila" que caracterizó a numerosas capitales de provincias del interior agrario español, débilmente urbanizadas, como las que actualmente conforman la región castellano-manchega ${ }^{22}$. Pero sería un error considerar que esta ciudad quedó por ello al margen del intenso proceso de democratización que se inició en Septiembre de 1868 y se prolongó en los años posteriores. Fue, precisamente, a partir de 1869 cuando los signos de politización en la población conquense adquirieron una mayor visibilidad que se evidenció, además, en un incremento de la competencia entre diversas sensibilidades politicas.

Analizar ese proceso de politización desde la escala de una ciudad paradigmática de la España interior y evaluar el papel que en el mismo jugaron dos culturas monárquicas radicalmente confrontadas, es el principal objetivo de este artículo. Sin menospreciar el valor que pueden aportar los estudios electorales como un indice del aprendizaje de la politica -sobre todo en un contexto marcado por la implantación del sufragio universal masculino-, se ha optado por prestar una mayor atención a otro tipo de prácticas sociales. Se aborda, en este sentido, una aproximación a la sociabilidad, tanto en su vertiente formal, en la medida que ayudó a la definición de diferentes identidades partidarias, como en su faceta informal, en la que también fue sensible la codificación de comportamientos marcados por la rivalidad política ${ }^{23}$. De igual

\footnotetext{
18 Ibid, pp. 204-205.
}

19 Sobre "la fiesta revolucionaria", Gregorio de la Fuente Monge, Los revolucionarios de 1868. Elites y poder en la España liberal, Marcial Pons, Madrid, 2000, pp. 92-107; la incidencia de la Gloriosa en la construcción iconográfica de la idea de España en Juan Francisco Fuentes, "Iconografía de la idea de España en la segunda mitad del siglo XIX", Cercles: revista d'història cultural, 5 (2002), pp. 8-25, p. 16. Asimismo, véase Sergio Sánchez Collantes, “Los bustos como simbolo del cambio político en 1868", Atlántica XXII: revista asturiana de información y pensamiento, $\mathrm{n}^{\circ}$ 42, 2016, pp. 54-56; del mismo autor, "La construcción simbólica del republicanismo español en el Sexenio Democrático", Investigaciones Históricas, n 37, 2017, pp. 132-174.

20 AMCU, Libro de Actas del Ayuntamiento de Cuenca, leg. 398, exp. 1, 30-9-1868.

${ }^{21}$ AMCU, “Junta revolucionaria”, leg. 670, exp. 8.

22 Rafael Villena Espinosa, "La revolución tranquila: el despliegue de la Gloriosa en la España interior", Ayer, $\mathrm{n}^{\circ}$ 112, 2018, pp. 47-72.

23 Sobre el concepto de sociabilidad en sus vertientes asociativa y relacional, junto a otras referencias anteriormente referenciadas, baste con citar las siguientes aproximaciones: Maurice 
manera, se analiza tanto la irrupción de formas modernas de movilización como las manifestaciones y la redefinición de los rituales de raíz religiosa para defender valores políticos ${ }^{24}$.

\section{SIGNOS DE POLITIZACIÓN EN UNA CAPITAL “DE TERCER ORDEN”}

A fines de junio de 1869, El Eco de Cuenca, órgano de los progresistas radicales de la ciudad, advertía con preocupación que los carlistas comenzaban dar la cara. Fue justo entonces cuando el uso de la margarita, símbolo que aludia a Margarita de Borbón-Parma, esposa del pretendiente Carlos María de Borbón, comenzó a generalizarse entre sus partidarios ${ }^{25}$. Era una manera de reafirmar su identidad politica en el espacio público, a la vez que se visibilizaba la desafección respecto a las nuevas instituciones. En esos momentos, cuando terminaba de promulgarse la Constitución, los rumores sobre un inminente levantamiento contrarrevolucionario eran constantes. El diputado conquense Vicente Romero Girón había contribuido a alentarlos al denunciar en las Cortes "los graves y casi públicos trabajos carlistas que se estlaban] haciendo en Cuenca, en un centro constituido por cuatro canónigos, según se dice, auxiliados por el Ilmo. Señor Obispo de la diócesis"26. De hecho, la Catedral había sido registrada por el ejército en busca de un cabecilla carlista ${ }^{27}$.

En ese contexto, los liberales conquenses interpretaron como una provocación la exhibición de las margaritas:

"El domingo por la tarde lucian los carlistas en las calles y paseos de esta capital la rosa hoy en boga entre ellos, como distintivo de tales, llamada margarideta (margarita), sin que, como es natural, nadie los molestara en su inocente ostentación. Por el contrario [...] en las vueltas de la Glorieta, siempre que se cruzaban con unos voluntarios de la Libertad, que paseaban en dirección inversa, observaron en aquellos cierta risita burlona y disimulada, de que estos no hicieron caso"28.

Agulhon, El circulo burgués, Siglo XXI, Buenos Aires, 2009; Elena Maza Zorrilla, Discurrir asociativo en la España contemporánea (1839-1941), Universidad de Valladolid, Valladolid, 2017, pp. 9-27; Ramón Arnabat y Montserrat Duch, "Sociabilidades contemporáneas", en Ramón Arnabat y Montserrat Duch (coords.), Historia de la sociabilidad contemporánea. Del asociacionismo a las redes sociales", Universitat de València, Valencia, 2014, pp. 9-21 y Jordi Canal i Morell, "La sociabilidad en los estudios sobre la España contemporánea: una revisión", en Elena Maza Zorrilla (coord.), Sociabilidad en la España contemporánea. Historiografía y problemas metodológicos, Universidad de Valladolid, Valladolid, 2002, pp. 35-55.

24 Se ha tenido en cuenta, en este sentido, el marco interpretativo sobre los repertorios tradicionales y modernos de movilización y su relevancia en la aparición del movimiento social nacional que expone Sidney G. Tarrow, El poder en movimiento. Los movimientos sociales, la acción colectiva y la politica, Alianza, Madrid, 2011.

25 Identifica el uso de la margarita como un dispositivo de poder vinculado a la cultura carlista Lluís Ferran Toledano, "El crucifijo y el baile", op. cit., p. 85.

26 Diario de Sesiones de las Cortes, $\mathrm{n}^{\circ} 39,1-4-1869$, p. 785.

27 El Pensamiento Español, 12-4-1869.

28 El Eco de Cuenca, 23-6-1869. 
En los meses anteriores se habian producido algunas manifestaciones esporádicas de disconformidad con la situación política. Sus protagonistas, más que los republicanos, con escasa presencia en Cuenca, fueron los sectores ultracatólicos vinculados a la dinastía caída y a la causa carlista ${ }^{29}$. Meses más tarde, las demostraciones de desafección se normalizaron. A ello contribuyó la actitud beligerante del episcopado conquense. A pesar de que el obispo no había logrado representación en las Constituyentes, adquirió una considerable visibilidad pública en los debates sobre la libertad religiosa a través de sus pastorales y de las protestas que elevó a las Cortes ${ }^{30}$. La defensa de la unidad católica de España fue, en este sentido, un eficaz catalizador para la movilización ultramonárquica y acentuó decisivamente el proceso de concentración de las distintas familias antiliberales en un mismo espacio político.

El resultado de esa convergencia fue la organización de la Comunión Católica-Monárquica, expresión de un carlismo renovado con la incorporación del grueso del antiguo grupo neocatólico. Se trataba de sacar rendimiento de las oportunidades creadas por el nuevo marco político mediante la lucha legal ${ }^{31}$. La organización del partido, en Cuenca, fue tardia, pero la movilización carlista fue sensible desde mediados de 1869. En agosto, por ejemplo, la prensa carlista informó que habían sido liberados diecisiete sujetos detenidos en Cuenca por dar vivas al general Cabrera ${ }^{32}$. El cambio politico, sin duda, había contribuido a elevar la temperatura política en la ciudad. No sólo entre los sectores contrarrevolucionarios, sino también entre las filas progresistas. Los propios dirigentes de la milicia ciudadana, redactores, a su vez, de El Eco de Cuenca dieron cuenta de ello. Lo hicieron, eso sí, mostrando un cierto recelo ante el inesperado incremento de los apoyos a la causa liberal:

"Cuando recordamos el periodo desde julio de 1856 al 29 de septiembre del 68, día del alzamiento en esta capital, y comparamos el entonces con el ahora, no podemos darnos razón de un cambio tan radical en las personas y en tan corto tiempo. Porque, es lo cierto que en dicho periodo nos contábamos los verdaderos liberales; $y$, preciso es confesarlo, éramos muy escasos en verdad, pues apenas llegarian a poco más de un centenar, a cuyo número, verificada la unión de las otras fracciones, podría añadirse una veintena entre demócratas y unionistas [...] ¿Cómo es que ahora se cuentan 350 Voluntarios de la Libertad inscritos, cuando entonces solo podriamos haber formado 200 ?'33.

Cabe advertir que ese centenar de "verdaderos liberales", en una pequeña ciudad provinciana como Cuenca, que no llegaba a los ocho mil habitantes, no era una cifra insignificante. Sobre todo si se tiene en cuenta que esta población había sido un feudo neocatólico controlado por la red clientelar tejida por Severo Catalina, ministro de los últimos gabinetes de Isabel II, y por el obispo de la

\footnotetext{
29 El Imparcial, 28-3-1869.

30 La Esperanza, 18 y 20-1, 12-5, 12-7 y 28-9-1869.

31 Sobre la incorporación de los "neos" a las filas carlistas, véase Begoña Urigüen, Orígenes y evolución de la derecha española: el neocatolicismo, CSIC, Madrid, 1986, pp. 289 y ss.
}

32 La Esperanza y La Regeneración, 2-8-1869.

33 El Eco de Cuenca, 24-3-1869. 
diócesis, el alicantino Miguel Payá y Rico ${ }^{34}$. El derribo de la monarquía de Isabel II, sostenida sobre un marco restrictivo de derechos y libertades, estimuló la politización de todas las capas sociales hasta el punto de provocar la desconfianza de muchos dirigentes revolucionarios, todavía anclados en una cultura de la movilización con residuos elitistas.

Idéntico recelo mostró el veterano progresista Fermín Caballero al evaluar la situación de la prensa conquense tras la ruptura revolucionaria ${ }^{35}$. Desde su punto de vista, ligado a la tradición liberal de la Constitución de 1837, la apertura politica de una sociedad debía ajustarse al ritmo del progreso económico y cultural. La proliferación de medios periodísticos y su circulación podían tomarse como un índice de ese progreso material y "moral". En el caso de una ciudad "de tercer orden" como Cuenca, no era extraño que hubiera "costado esfuerzos reiterados y perseverantes aclimatar periódicos de localidad"36. Los elevados indices de analfabetismo, la escasa "afición a la lectura y menos a la politica" y la carencia de medios pecuniarios constituían, en su opinión, un límite sociológico al desarrollo de la prensa - sobre todo política- y, por tanto, a la dilatación de la esfera pública.

Sin embargo, la libertad de imprenta decretada por el gobierno revolucionario había facilitado una inesperada multiplicación de cabeceras locales. Por extensión, cabría afirmar que "la afición a la politica" se había multiplicado en la misma proporción. O, simplemente, había quedado al descubierto el elevado grado de politización que se había desarrollado durante la crisis del reinado isabelino, a pesar del marco político restrictivo del doctrinarismo:

"La revolución de setiembre de 1868 ha destapado de tal modo las trabas [...] que el ansia de escribir raya en monomania, y por todas partes brotan periódicos diferentes, aún en poblaciones subalternas.

Cuenca ha seguido la corriente, [...] hace pocos meses en nuestra ciudad, que no llega a 7400 habitantes, salian al público ocho periódicos a la vez"37.

La "monomania" de escribir, leer o escuchar las lecturas públicas de la prensa constituía, de este modo, un claro signo de politización que podría extrapolarse a otros ámbitos. A pesar de la escasez de datos para su estudio, puede también comprobarse el considerable desarrollo que la vida asociativa de una "capital de tercer orden" como Cuenca experimentó con el despliegue de la democracia. Antes de

34 Cuenca había sido un verdadero feudo neocatólico y "una provincia dominada casi exclusivamente por el clero", según manifestaba el Gobernador Civil de Cuenca en 1865, apud. Juan Antonio Inarejos Muñoz, Ciudadanos, propietarios y electores en la construcción del liberalismo español. El caso de las provincias castellano-manchegas (1854-1868), Biblioteca Nueva, Madrid, 2008, p. 238.

35 Evalúan la incidencia del proceso revolucionario en la prensa local Ángel Luis López Villaverde e Isidro Sánchez Sánchez, Historia y evolución de la prensa conquense (1811-1939), UCLM, Cuenca, pp. 35-39; incidencia, lógicamente, generalizada en el conjunto de España, como muestra Antonio Checa Godoy, El ejercicio de la libertad: la prensa española en el Sexenio Revolucionario (1868-1874), Biblioteca Nueva, Madrid, 2006.

36 Fermín Caballero, La Imprenta en Cuenca. Datos para la historia del arte tipográfico en España, Imprenta de El Eco de Cuenca, Cuenca, 1869, p. 104.

37 Ibid. p. 108. 
la Gloriosa, las clases medias de la capital conquense contaban con un único espacio de sociabilidad formal, el Casino Artístico situado en la calle de Madereros. A pesar de estar destinado "únicamente al recreo y esparcimiento", la distribución de sus socios en diferentes mesas revelaba sus afinidades politicas. Como recordaban los progresistas en 1869, la que ellos ocupaban "fue bautizada" por los moderados "con el nombre de mesa negra o del crimen"38.

El Casino Artístico sobrevivió pocos meses a la Gloriosa. A fines de enero de 1869, El Eco de Cuenca anunciaba la subasta de "todas las piezas del mobiliario y enseres del establecimiento"39. Parece, por ello, que se procedía a su liquidación. Pocos días antes, la prensa católica recogió un hecho significativo: el día 13, dos conocidos carlistas de la ciudad fueron acometidos por un grupo de hombres "sable en mano" cuando salian del Casino 40 . En esos momentos comenzaban las elecciones a Cortes Constituyentes. Una candidatura neocatólica, encabezada por el obispo y por el lectoral, se presentaba frente a las diferentes listas liberales. Parece que la agresión era una advertencia para amedrentar al electorado antiliberal. Según indicaba La Esperanza, veterana cabecera carlista, "la noche anterior, las casas de los católicos fueron señaladas con una cruz roja"41.

Al hablar de "católicos", por supuesto, se referian a ese margen de afinidad politica que aglutinaba, en torno a la doctrina del Syllabus, a la extrema derecha del antiguo moderantismo y a los partidarios de Carlos VII. En medio de múltiples y constantes rumores sobre la inminencia de un alzamiento carlista, la hostilidad de los liberales más radicalizados se proyectó sobre las fachadas de algunos domicilios particulares con pintadas y "letreros escandalosos y amenazadores" 42. Significativamente, el Palacio Episcopal, eje de la oposición a las nuevas instituciones en la ciudad, no escapó a estas demostraciones de rechazo. Todo ello era un síntoma de la acusada polarización política que se vivía en esos momentos. La convivencia de los socios de adscripciones partidarias rivales siempre había sido tensa en el Casino, pero en ese nuevo contexto parecía insostenible.

Por otra parte, la recién conquistada libertad de asociación ya no ponía trabas a la apertura de nuevos espacios que fueran más allá del "recreo y el esparcimiento" para asumir una orientación decididamente política. Por ello, la desaparición del Casino Artístico, lejos de significar un retroceso de la sociabilidad formal, fue la antesala de una mayor pluralidad asociativa. La iniciativa más temprana y ambiciosa, en este sentido, fue el Círculo Popular Conquense $^{43}$. Un proyecto que la prensa progresista local presentaba del

38 El Eco de Cuenca, 24-3-1869.

39 El Eco de Cuenca, 21-1-1869.

40 La Regeneración, 18-1-1869.

${ }^{41}$ La Esperanza, 19-1-1869.

42 La Esperanza, 19-1-1869. En Tortosa aparecieron horcas pintadas en las puertas de algunos electores católico-monárquicos, según William J. Callahan, Iglesia, poder y sociedad en España, 1750-1874, op. cit. p. 247.

${ }^{43} \mathrm{El}$ análisis que sigue sobre la sociabilidad formal en Cuenca se limita a aquellas asociaciones que tuvieron una incidencia clara sobre la movilización politica de la ciudad. Queda por ello al margen la aparición en 1870 de una logia masónica dependiente del Gran Oriente de España, llamada Catoniana, vinculada con los dirigentes radicales. Véase al respecto José Antonio Ferrer Benimeli, "Implantación de logias y distribución geográfico-histórica de la masonería española", en 
siguiente modo:

"Se trata de formar en esta capital un centro de ilustración y recreo, con escuela de adultos, cátedras de Geografia, Historia, Matemáticas, Dibujo y Solfeo, Gabinete de lectura y Casino, teniendo a la vez el proyecto de dar algunas funciones de baile y de crear una biblioteca para los socios y para el público que de ella se quiera utilizar.

Grandes son, sin duda, los beneficios que de esta clase de asociaciones reportan los pueblos donde se establecen, pudiéndose medir su civilización y cultura por el número de aquellas en que cada uno existen"44.

E1 Círculo Popular, de este modo, trataba de conjugar propósitos educativos y formativos, como centro de enseñanza libre, y el ocio, al albergar un nuevo casino, pero también mediante actividades no estrictamente cerradas a los socios. En su "Crónica de la Enseñanza", José Fernando González definió esta asociación como "una especie de liceo" que, "entre otras ventajas", tenía la de contar con el respaldo de "todas las fuerzas vivas $e$ inteligentes de aquella localidad". Por ellas debe entenderse a una buena parte de los dirigentes del Partido Progresista en la ciudad, incluido el director y algunos catedráticos del Instituto, que impulsaron la iniciativa. La estrategia era atraer afluencia al Círculo Popular "de una manera indirecta" mediante "algún aliciente de curiosidad o distracción licita y honesta" 45.

La sociedad fue inaugurada en la calle Caballeros, dentro de la ciudad intramuros, con una muestra de dichos alicientes: un baile de máscaras, al que siguieron conciertos, bailes "de confianza", "de sociedad", "de piñata", etcétera46. Debe, por otra parte, advertirse que el Círculo Popular no quedó al margen de los propósitos políticos que identificaban a sus promotores. De este modo, tanto las diversiones "licitas y honestas" como el despliegue de la enseñanza popular favorecieron, "de una manera indirecta", el proselitismo progresista-democrático. Es significativo que, desde la escisión de los progresistas conservadores de Sagasta en octubre de 1871 , los radicales comenzaron a celebrar sus reuniones y asambleas en este espacio, que terminó solapándose con el Círculo Radical ${ }^{47}$.

Por supuesto, los sectores monárquico-católicos de la población respondieron a sus rivales democráta-monárquicos con la organización de sus propios centros de sociabilidad: "Se nos asegura -informaba El Eco a comienzos de 1870- que los constantes favorecedores de la idea absolutista están haciendo grandes trabajos para constituir en esta capital una sociedad con el titulo de

José Antonio Ferrer Benimeli (coord), La masoneria española en el s. XIX, vol. 1, Junta de Castilla y León, Salamanca, 1987, pp. 76 y 97; Ángel Luis López Villaverde y Ángel Ramón del Valle Calzado, "Masonería de la Mancha conquense a fines del s. XIX, en José Antonio Ferrer Benimeli, La masonería española y la crisis colonial del 98, vol. 2, Centro de Estudios Históricos de la Masonería Española, Zaragoza, 1999, pp. 865-878.

44 El Eco de Cuenca, 5-1-1870.

45 José Fernando González, "Crónica de la enseñanza", Boletín-Revista de la Universidad de Madrid, no 16, 25-5-1870, t. II, Establecimiento Tipográfico de Tomás Rey, Madrid, p. 1082.

46 El Eco de Cuenca, 16-2-1870, 19-2-1870, 20-4-1870, 28-2-1871, 9-9-1871, 15-11-1871.

47 El Eco de Cuenca, 25-10-1871, 11-11-1871, 15-11-1871. 
Juventud Católica"48. En las mismas fechas, multitud de centros con la misma denominación habían comenzado a extenderse por diversas ciudades españolas. La Juventud Católica fue un apéndice especialmente activo de la Asociación de Católicos ${ }^{49}$. Aunque no de manera expresa, sus vínculos con el movimiento carlista eran patentes.

Los promotores de esta asociación trataron de dejar la cuestión dinástica en un segundo plano y centrarse en la defensa del integrismo católico: "el fin de la academia que hoy se inaugura, hedlo aqui resumido en pocos términos: con Dios $y$ su Religión santa, que es la católica, apostólica, romana, todo; sin Dios y sin su Religión sacrosanta nada, absolutamente nada", sostenía un orador en su acto de inauguración. Por ello remarcaron que alli se congregaban "hombres de todas las clases $y$ de diferentes opiniones politicas"50. Toda esa diversidad, sin embargo, podia reducirse a un mismo magma integrista que terminó capitalizado por el carlismo. La firma de su presidente, el seminarista Pascual Carrascosa, no se encuentra entre los componentes de los comités carlistas ni al pie de los manifiestos de esta agrupación. Sí cabe rastrear la de algunos de sus académicos más activos. Fue el caso de Santiago Salamanca, que en mayo de 1870 firmó un manifiesto de adhesión al pretendiente ${ }^{51}$. No es, por ello, extraño que los progresistas les calificaran como la "Juventud carlista"

A mediados del mismo año, hay constancia también de la existencia de un Club Republicano en la capital53. De su actividad no ha quedado rastro en la prensa, ni se conservan sus estatutos. Cabe suponer, por analogía, que sus fines y funcionamiento no diferian de los que guiaron a otras sociedades de las mismas características en otros puntos del país. Junto a las redacciones de los periódicos y la red de comités locales y provinciales, tuvieron un papel crucial en la expansión del movimiento republicano como escuelas de democracia, sustentadas en la horizontalidad de las relaciones y el trato igualitario ${ }^{54}$. De ello han dado cuenta, entre otros, los estudios de Rosana Gutiérrez Lloret y Manuel Morales para los casos de Alicante y Málaga. La diferencia, en este sentido, estriba en la escasa penetración social que caracterizó al federalismo conquense

48 El Eco de Cuenca, 26-3-1870.

49 Begoña Urigüen, Orígenes y evolución de la derecha española: el neocatolicismo, op. cit., p. 364. De acuerdo a los datos recogidos por la misma autora (pp. 367-368), en torno a 1870 apareció también una Junta de la Asociación de Católicos en Cuenca. No se ha encontrado rastro documental de la misma. Sobre los vínculos entre la Asociación de Católicos y la Comunión Católico-Monárquica, William J. Callahan, Iglesia, poder y sociedad en España, 1750-1874, op. cit. pp. 246-247.

50 El Pensamiento Español, 13-4-1870.

51 El Eco de Cuenca, 18-5-1870. Santiago Molero y Pascual Carrascosa acudieron en representación de la provincia de Cuenca a la Asamblea General de la Juventud Católica de España, celebrada en marzo de 1870, El Pensamiento Español, 10-4-1870.

52 El Eco de Cuenca, 26-3-1870.

53 La Discusión, 28-8-1870.

54 Rosa Ana Gutiérrez Lloret, "Sociabilidad, propaganda y cultura tras la revolución de 1868: los clubes republicanos en el Sexenio Democrático", Ayer, no 44, 2001, pp. 151-174; Manuel Morales Muñoz, El republicanismo malagueño en el siglo XIX. Propaganda doctrinal, prácticas politicas y formas de sociabilidad, Auskaria, Málaga, 1999; del mismo autor: "El porvenir de la libertad'. Cultura y sociabilidad republicanas en los siglos XIX y XX", en Ramón Arnabat y Montserrat Duch (coords.), Historia de la sociabilidad contemporánea, op. cit. pp. 203-122. 
hasta 1873. Sin ser una fuerza irrelevante, lo cierto es que el republicanismo contó con unas limitadas bases militantes en la provincia ${ }^{55}$.

La actividad de estos centros no se limitó al espacio de sus locales. Por el contrario, asumieron una función central en la organización de conmemoraciones, reuniones públicas y, en el caso de la Juventud Católica, funciones religiosas tanto en los templos como al aire libre. Impulsaron, por tanto, una batalla por la apropiación simbólica del espacio público. La calle se convirtió en objeto de disputa por la hegemonía política de la ciudad y, a la vez, en escenario de una innegable modernización de las estrategias de movilización desplegadas por diferentes agrupaciones. Las manifestaciones, sin duda, fueron la mayor novedad. A menudo, sin embargo, las expresiones más tradicionales de las fiestas populares y religiosas actuaron también como vehículo de una modernización alternativa, con la adherencia de nuevos componentes reivindicativos ${ }^{56}$.

\section{LA DIFÍCIL CONSOLIDACIÓN DE LA FIESTA REVOLUCIONARIA}

El análisis de las fiestas y celebraciones oficiales promovidas por las instituciones en Cuenca permite comprobar las dificultades que encontró el régimen instaurado por la Revolución de Septiembre a la hora de fomentar un nuevo calendario conmemorativo de carácter cívico. Este adjetivo, como observa Alicia Mira para el caso de Alicante, resulta problemático si se le asocia "una voluntad secularizadora y la intención de crear una alternativa laica a las celebraciones católicas" 57 . A pesar del generalizado rechazo a la Constitución de 1869 entre el clero conquense, ni el obispo ni el cabildo catedralicio faltaron a los actos programados para celebrar su proclamación ${ }^{58}$. Su participación, sin embargo, no significaba en absoluto una muestra de adhesión. Así se lo comunicaba el propio obispo, Miguel Payá, al nuncio papal:

"Anteayer fuimos sorprendidos por una invitación de este señor gobernador civil para asistir a la solemne promulgación de la Constitución nueva en un tablado levantado en la plaza principal de esta ciudad. No puedo expresar a V. E. lo que mi espíritu ha padecido en el periodo de 24 horas. Por una parte, tanto mi cabildo como yo estamos resueltos a no aprobar nunca, ni aún a la vista del patíbulo, cosa alguna que la Iglesia repruebe, y por otra, sabiendo que se nos mira con tanta prevención [...], temíamos provocar alguna deshecha borrasca sobre esta santa Iglesia. En vista de todo esto, [...] mandé a mi provisor y secretario a que manifestaran al señor gobernador si tendría a bien disculparles la asistencia, y en caso

55 Eduardo Higueras Castañeda, Pablo Correa y Zafrilla (1842-1888): Republicanismo y cuestión social en la España del Ochocientos, Toledo, Almud, pp. 63-68.

56 Son de especial interés en este sentido las reflexiones de Caroline Ford, "The use and practice of tradition in the politicization of rural France during the Nineteenth Century", en La politisation des campagnes au XIXe Siècle, op. cit., pp. 327-341.

57 Alicia Mira Abad, Secularización y mentalidades. El Sexenio Democrático en Alicante (18681875), op. cit. p. 204.

58 El Eco de Cuenca, 9-6-1869. "Los capitulares y beneficiados de la santa iglesia catedral basílica de Cuenca, han acordado unánimemente no prestar el juramento [a la Constitución] exigido por decreto de 17 de marzo último", informaba La Regeneración, 5-4-1869. 
negativo que entendiera que nuestra presencia en el acto no significaba aprobación absoluta, sino simple cortesia y asistencia a oir la intimación. El señor gobernador les dijo que podiamos hacer lo que quisiésemos, pero que no respondia de las consecuencias, y en cuanto a lo segundo, estaba conforme con nuestras salvedades. En consecuencia, asistimos, pero en actitud tan triste que el pueblo ha comprendido lo que nosotros queriamos; a saber, que no sancionábamos, sino que sufriamos"59.

El día 6 de junio "un clamor general de campanas" anunció el comienzo de las celebraciones. La fiesta tenía como objeto fundamental el juramento del nuevo código fundamental "por las autoridades y funcionarios civiles y batallón de Voluntarios de la Libertad"60. Se organizó, para ello, una procesión cívica que comenzaba en la Diputación Provincial y ascendia por la calle Correduría hasta la plaza Mayor, rebautizada como plaza de la Constitución, frente al Ayuntamiento y la Catedral. Este breve itinerario unía los dos principales espacios de poder de la población. La comitiva estaba formada por representantes de las diferentes corporaciones de la ciudad. Eran "las fuerzas vivas" de Cuenca: funcionarios, regidores, oficiales del ejército, jefes de la milicia, el cuerpo de ingenieros, colegio de abogados, el claustro de catedráticos del instituto, el juzgado " $y$ algunas individualidades más"61.

El gobernador civil, el comandante militar y el obispo, máximos representantes del mundo oficial en la provincia, presidieron el acto que se celebró en la plaza de la Constitución. La participación ciudadana, por tanto, se limitaba al papel de espectador. Seguramente de manera exagerada, El Eco aludía al "numeroso público que acudió a presenciar tan grandioso acto". Las autoridades y las fuerzas politicas más identificadas con el proyecto revolucionario trataron, eso si, de estimular las demostraciones de adhesión con iluminaciones y decoración en los balcones. Era, por supuesto, una práctica limitada a las capas más acomodadas de la población que residian, precisamente, en las calles por donde transcurrian este tipo de desfiles. A esos mismos sectores sociales estaba, asimismo, reservada otra importante parte de los actos conmemorativos, como el baile que el Gobernador Civil dio "en los salones de la Diputación provincial"62.

La celebración, por tanto, mostraba una estratificación social de la fiesta que situaba en la cúspide a los representantes del Estado, del ejército y de la Iglesia. En ella, las clases populares tenian una participación diferenciada. Frente al baile "de sociedad" de las autoridades y las clases acomodadas, el resto de la población pudo disfrutar de la "iluminación general y música" en la Plaza Mayor ${ }^{63}$. La caridad, por último, constituía una práctica ineludible en cualquier conmemoración oficial. Con ella se demarcaban los últimos estratos sociales, definidos por el umbral de la necesidad. A la vez, la beneficencia fue utilizada

59 Carta de Miguel Payá a Franchi, Cuenca, 7-6-1869, apud Vicente Cárcel Ortí, Iglesia y Revolución en España (1869-1874), Eunsa, Pamplona, 1979, pp. 410-411.

60 El Eco de Cuenca, 26-6-1869 y AMCU, “Constitución: juramento”, leg. 728-19.

61 El Eco de Cuenca, 9-6-1869.

62 El Eco de Cuenca, 26-6-1869.

63 El Eco de Cuenca, 9-6-1869. 
como un medio de transmisión de valores políticos o cívicos sobre las clases desfavorecidas ${ }^{64}$. La Diputación, en este sentido, organizó el reparto de "1200 libras de pan para los pobres, en el exconvento de San Pablo, y a las doce [justo a la hora prevista para el juramento de la Constitución por las autoridades] una abundante comida a los presos de la cárcel"65.

Este modelo de fiesta oficial refleja con bastante exactitud el esquema tradicional que describió Maurice Agulhon para las celebraciones de la Francia rural en la primera mitad del siglo XIX. No faltaba ninguno de los elementos comunes de este tipo de conmemoración: el anuncio mediante campanadas y salvas, el desfile de la población en cuerpo, conforme a una jerarquía social con ecos viejo-regimentales, los "festejos" o diversiones en forma de banquetes, música y bailes populares, y la distribución de pan a los pobres. Sin embargo, pueden comprobarse también algunas diferencias significativas. De entrada, no fueron las campanas de las parroquias las que anunciaron estas celebraciones, sino las de la torre-reloj de Mangana, un edificio civil gestionado por el ayuntamiento. Las crónicas, por otra parte, tampoco aluden a la celebración de la habitual "misa solemne". Fuera debido a la resistencia del clero o a la convicción laicista de las autoridades, lo anterior denota un cierto avance secularizador ${ }^{66}$.

La promulgación de la Constitución no dio lugar a una festividad periódica con la que escenificar la adhesión a los principios monárquico-democráticos. Ni en 1870 ni en los años posteriores volvió a celebrarse la efeméride. Lo mismo ocurrió con las conmemoraciones ligadas a la monarquía de Amadeo I. Un reinado, como se ha repetido en muchas ocasiones, que comenzó lastrado por el asesinato del general Prim, presidente del último gobierno de la Regencia y máximo dirigente de los progresistas, principales impulsores de la candidatura al trono de Amadeo de Saboya. El magnicidio contribuyó a enturbiar un ambiente poco propicio para conmemoraciones públicas. En Cuenca, las festividades destinadas a solemnizar la llegada del nuevo monarca se limitaron al reparto de caridad:

"Ayer, hoy y mañana se están repartiendo infinidad de libras de pan a todos los necesitados que se presentan en esta ciudad en los distritos de la Merced, Instituto y Misericordia vieja, por disposición del Ayuntamiento y como medio de solemnizar la coronación de Amadeo I, rey de España.

Celebramos que el municipio haya tenido tan oportuno pensamiento, en vez de adoptar funciones de pólvora y vaquillas, porque hubieran contrastado tristemente con el atribulado espiritu de todos los buenos liberales, que lloran aún y llorarán por mucho tiempo la muerte del malogrado patricio don Juan Prim"67.

Es cierto, por otra parte, que el recibimiento del nuevo monarca entre los

64 Pere Solà Gussinyer, "Apuntes para una historiografía de la sociabilidad catalana contemporánea en una perspectiva mediterránea comparada", en Ramón Arnabat y Montserrat Duch (coords.), Historia de la sociabilidad contemporánea, op. cit. pp. 23-38, p. 24.

65 El Eco de Cuenca, 26-6-1869.

66 Véase, Maurice Agulhon, La République au Village, op. cit., pp. 150-158.

67 El Eco de Cuenca, 7-1-1871. 
progresistas conquenses distó de ser caluroso: "la dinastía de Amadeo I [...] viene a implantarse en España sobre las ruinas del derecho divino y del antiguo régimen, sostenido por el ciego absolutismo, y a levantarse majestuoso sobre la sólida base [...] del derecho democrático proclamado por la revolución de este pueblo", afirmaba El Eco de Cuenca. Su saludo, sin embargo, concluía con una advertencia dirigida al rey: "que no olvide, como Isabel, que el pueblo liberal español pone en sus sienes la diadema real para que por él vele [...] que no lo olvide, pues, y su reinado será bendecido por todos"68. Al fin y al cabo, el órgano de los radicales conquenses habia defendido abierta e insistentemente la candidatura al trono del general Espartero. Ni siquiera renunció a ella tras el voto favorable de las Constituyentes al duque de Aosta, en noviembre de 1870.

La frialdad de la proclamación del monarca italiano fue, en parte, compensada con la celebración de su cumpleaños, el 30 de mayo de 1871. La conmemoración comenzó de madrugada con "el alegre tañer de [la torre de] Mangana", así como por el "toque de diana y salvas". El guion de la fiesta reproducía de nuevo el esquema habitual de las celebraciones oficiales: recepción de las autoridades, concentración de los Voluntarios de la Libertad en la plaza Mayor y, por la noche, "iluminación en la fachada de las Casas Consistoriales y las de casi todos los liberales de la población". Las fuerzas dinásticas exteriorizaban así "su aprecio hacia el monarca"69. Como novedad, el retrato del rey fue expuesto al público en los balcones del Ayuntamiento. La celebración, no obstante, no volvió a repetirse en los años siguientes.

Todo lo contrario ocurrió con el aniversario de la Revolución de 1868, que adquirió un carácter más popular que las anteriores. A ello, sin duda, contribuyó la proximidad de la tradicional festividad de San Mateo. Con ella se conmemoraba la conquista cristiana de la ciudad en 1177, y contaba con un hondo arraigo en la ciudad. Ya en septiembre de 1868, el ayuntamiento moderado había previsto vincular la festividad del día 21 con el aniversario del acceso al trono de Isabel II, que se celebraba en los días posteriores ${ }^{70}$. Programó, para ello, un encierro taurino. Paradójicamente, las vaquillas terminaron sirviendo para festejar el triunfo revolucionario y la caída de la reina ${ }^{71}$.

Los dirigentes liberales supieron conjugar la fiesta popular, de raíz religiosa, con la conmemoración civil. Así, trataban de resignificar la primera en clave revolucionaria. E1 "repique general de campanas al amanecer del 29" debía, en este sentido, simbolizar "el día que empezó para España la nueva era de nuestra regeneración social y politica". La parte institucional de la festividad, como era de rigor, se celebraba en la Plaza Mayor, frente al Ayuntamiento, con presencia de los Voluntarios de la Libertad. Alli, el alcalde leía al público "una alocución alusiva al acto" que más tarde era repartida entre la población. Por la tarde, comenzaban los festejos:

"A las cuatro de la tarde comenzarán a correrse en la misma plaza dos vaquillas enmaromadas, como es costumbre en la capital, con las cuales hará

68 El Eco de Cuenca, 4-1-1871.

69 El Eco de Cuenca, 1-4-1871.

70 AMCU, Libro de Actas, leg. 398-1, 16-9-1868.

71 Sinesio Barquín Armero, Los Voluntarios de la Libertad en la Ciudad de Cuenca (1868-1874), op. cit. p. 4. 
un obsequio después la corporación popular al Batallón de Voluntarios.

Por la noche habrá iluminación en las casas consistoriales, y en las de los vecinos que a ello se presten, asi como colgaduras en los balcones, previa invitación de la autoridad local.

La música de los Voluntarios de la Libertad, por su propio ofrecimiento, y la de Beneficencia según se nos dice, tocarán todo el día y parte de la noche piezas escogidas e himnos patrióticos para recreo y esparcimiento del vecindario"72.

La fuerza de Voluntarios tuvo un papel central en la festividad ${ }^{73}$. Era, al fin y al cabo, su comandante, el notario Isidoro Arribas, máximo dirigente de los radicales de Cuenca, quien regaló las vaquillas para el encierro. Pretendia, de este modo, reforzar la lealtad de la milicia, que constituía la principal base militante del radicalismo y, a la vez, promover los valores revolucionarios entre todas las capas sociales de la ciudad. Debe, en este sentido, subrayarse la relevancia de la música a la hora de transmitir simbolos y valores políticos ${ }^{74}$. A comienzos de 1869, El Eco de Cuenca, periódico en el que escribía el propio Arribas, no dudó en calificar de "patriótica" la iniciativa de un grupo de voluntarios de "formar una charanga" 75 . Ese adjetivo adquiere todo su sentido al comprobar, en primer lugar, que en la ciudad no existían más bandas de música que las de la Beneficencia y las cofradias ${ }^{76}$. De ellas no podía esperarse la interpretación de himnos patrióticos o la participación en actos de significación revolucionaria.

La conmemoración de la Revolución de Septiembre se celebró de manera ininterrumpida entre 1869 y 1871. El primer año, la lluvia y, al parecer, una cierta apatía deslucieron la fiesta. El Eco denunció "la falta de galantería con que respondió el vecindario en aquella noche a la invitación de la autoridad local, para que se iluminaran las ventanas y balcones". Fueron, al parecer, "muy contados los vecinos que correspondieron a su atenta excitación"77, lo que podia interpretarse como una escasa adhesión a las nuevas instituciones, o bien un desgaste de la popularidad de las mismas. No obstante, en los años siguientes la festividad tuvo un mayor respaldo ciudadano"7. Las vaquillas "hicieron bastante juego, sin desgracias, $y$ distrajeron gratamente a los vecinos" y a los visitantes. Los balcones "de muchas casas de los liberales", sin necesidad de aviso del ayuntamiento, "se vieron iluminados [...] con faroles de cristal y de colores"79.

72 El Eco de Cuenca, 29-9-1869.

73 AMCU, Libro de Actas del Ayuntamiento de Cuenca, leg. 400, 1-10-1870.

74 Así lo sugiere Maurice Agulhon, La République au Village. Les populations du Var de la Révolution a la II République, Seuil, Paris, 1979, p. 172.

75 El Eco de Cuenca, 21-3-1869.

76 El Eco de Cuenca, 1-4-1869.

77 El Eco de Cuenca, 2-10-1869

78 Una crónica del festejo en 1870, en El Eco de Cuenca, 28-9-1870 y 1-10-1870.

79 El Eco de Cuenca, 30-9-1871. 
El aniversario de la Septembrina, de este modo, fue la única festividad cívica que parecía poseer condiciones para consolidarse. Fue gracias, sobre todo, al atractivo de su parte más lúdica y a su conexión con una fiesta tradicional que conservaba toda su popularidad. La celebración, sin embargo, se interrumpió en septiembre de 1872. Ese año la efeméride pasó, conforme a la intencionada comparación de El Eco, "ni más ni menos que cualquier miércoles de ceniza". El motivo tenía que ver con el hecho de "ser carlista la mayoría del ayuntamiento, refractario y enemigo de aquel movimiento popular" 80 . La Comunión CatólicoMonárquica, en efecto, se había impuesto a una candidatura radical apoyada por los republicanos en las elecciones de diciembre de 1871. Los carlistas vencieron en los tres colegios de la ciudad intramuros. Sólo en el de San Francisco, en la parte moderna de la ciudad, consiguieron imponerse los radicales ${ }^{81}$.

Con un índice de participación del 74\% y 11 concejales frente a 3 , la victoria carlista fue contundente, aunque engañosa. Sumados todos los votos, la ventaja quedaba reducida únicamente a 85 papeletas. Una estrecha distancia que revela, de un lado, una fuerte movilización electoral, reflejo de la intensa polarización politica que se atravesaba y, de otro, el equilibrio de fuerzas existente entre los partidarios de Carlos María de Borbón y los progresista-demócratas, con sus respectivos aliados. A la hora de evaluar el resultado, sin embargo, los radicales tenían claro que la clave de su derrota, por encima de las cuestiones dinásticas, tenía que ver con las influencias clericales y la clara apuesta del obispo por los carlistas. Entre las diversas derechas católicas, en el contexto de la lucha electoral, eran ellos quienes contaban con la mejor posición para defender los intereses tradicionalistas:

Ha votado todo el clero catedralicio y parroquial, los sacristanes, los acólitos, los músicos, los cantores y familiares, fámulos y seminaristas de San Julián y San Pablo, y todo el que con sufragio ha tenido a bien ejercitar su derecho, excepto el señor arcediano, el señor abad y el señor obispo, si bien con las influencias propias de su carácter han visitado a todas o la mayor parte de sus humildes ovejas, y mandado recaditos de atención, envueltos con alguno que otro apercibimiento, llevando muchos electores que antes votaron a Catalina, a Coronado y a Flaguera; en una palabra, alfonsinos unos $y$ montpensieristas otros ${ }^{82}$.

El ayuntamiento fue destituido el 27 de abril de $1872^{83}$. El pretexto fue el levantamiento carlista con el que el pretendiente puso fin a la estrategia legal promovida por Cándido Nocedal. En lugar de los concejales carlistas, el gobernador designó a una serie de personalidades vinculadas al liberalismo conservador y al Partido Radical. Los representantes de esta última agrupación, sin embargo, rehusaron el nombramiento. Argumentaban que sólo la confianza de los ciudadanos a través del sufragio legitimaba el ejercicio de una responsabilidad pública. Por ello, cuando en julio de ese mismo año Ruiz Zorrilla

80 El Eco de Cuenca, 2-10-1872.

81 AMCU, leg. 613, exp. 2.

82 El Eco de Cuenca, 13-12-1871.

83 AMCU, leg. 613, exp. 3. 
formó un gobierno radical, apoyaron la reposición del ayuntamiento carlista ${ }^{84}$. Fue, precisamente, el consistorio restituido el que eliminó los festejos conmemorativos de la Revolución.

\section{LOS RADICALES EN LA CALLE: DE AMADEO I A LA REPÚBLICA}

Desde el triunfo de la Revolución de Septiembre, la cuestión de la forma de gobierno que debía adoptarse en España dividió a la opinión pública. La eclosión republicana que se experimentó en esos momentos fue un síntoma de que esa preocupación iba más allá de las élites políticas y se extendía también entre las clases populares ${ }^{85}$. No en todos los espacios del país, sin embargo, el federalismo contó con el mismo respaldo entre las masas, lo que no significa que permanecieran al margen del impulso modernizador que esa opción politica representaba. La posibilidad de lograr la unión ibérica por la vía monárquica, por ejemplo, o el proyecto de definir una monarquía electiva popular y democrática, representada por el general Espartero, gozaron también de una fuerte capacidad de movilización que fue aprovechada por otros movimientos políticos ${ }^{86}$.

La problemática de las candidaturas al trono ha sido tratada, generalmente, como una historia estrictamente diplomática o explicada desde el nivel de los máximos dirigentes nacionales que intervinieron en las negociaciones, como si se tratara de una cuestión ajena a las preocupaciones de la mayor parte de la población. Puede, sin embargo, ofrecerse un ejemplo para matizar esa idea. A fines de febrero de 1869, el veterano progresista Fermín Caballero y su primo Florentino Aparicio preparaban un viaje a un municipio conquense. La efervescencia que la candidatura de Fernando de Coburgo había generado, sin embargo, aconsejaba aplazar esa visita: "si no hay paz completa aqui [Barajas de Melo] y allá debemos suspenderlo —escribía el segundo-. Tal vez con la cuestión palpitante de Unión Ibérica, pudieran suscitarse algunos disturbios entre los que la quieren y rechazan en ambos pueblos"87. En la España rural, de este modo, podia también medirse un intenso pulso político, y la cuestión de la forma del Estado palpitaba con fuerza.

Por supuesto, no se trataba de un simple debate teórico, sino que implicaba importantes consecuencias en el terreno social. Por ello generó una movilización que se dejó sentir con fuerza en las calles. La libertad de reunión, proclamada en las primeras decisiones de las Juntas revolucionarias y en los decretos del

84 AMCU, Libro de Actas, 7-7-1872.

85 Sobre el movimiento republicano en el Sexenio, baste con citar los trabajos de Àngel Duarte, El republicanismo: una pasión politica, Cátedra, Madrid, 2014, pp. 87 y ss; y Román Miguel González, La Pasión Revolucionaria. Culturas politicas republicanas y movilización popular en la España del siglo XIX, CEPC, Madrid, 2007, pp. 150 y ss.

86 Acerca del movimiento esparterista, baste con citar las investigaciones de Pablo Sáez Miguel, "Espartero o el Cincinato español. Historia de la candidatura a Rey del duque de la Victoria (18681870)", Berceo, $\mathrm{n}^{\circ}$ 160, pp. 119-144; y la reciente biografia de Adrian Shubert, Espartero, el Pacificador, Galaxia Gutemberg, Madrid, 2018, pp. 455-506. Sobre el movimiento iberista en el Sexenio debe destacarse la investigación de Pablo Hernández Ramos, El iberismo en la prensa de Madrid, 1840-1874. Análisis cuantitativo-discursivo del nacionalismo ibérico desde los textos periodisticos, Tesis Doctoral, Universidad Complutense de Madrid, 2015.

87 Florentino Aparicio a Fermín Caballero, Barajas de Melo, 23-2-1869, Real Academia de la Historia, Archivo Fermin Caballero. 
Gobierno Provisional, fue recogida también entre los derechos individuales del Título I de la Constitución de 1869. Con ella, la manifestación se convirtió en una práctica cada vez más habitual con la que los movimientos políticos intervenían sobre la esfera pública. Frente al tradicional recelo del liberalismo ante la movilización popular y la participación de las masas en los espacios de acción política $^{88}$, las culturas democráticas recurrieron con frecuencia a este tipo de movilizaciones para defender y propagar sus postulados. La expansión de las reuniones públicas significaba, en definitiva, un índice de modernización política.

En Cuenca, el primer intento de organizar una manifestación se debió a la iniciativa de los federales a fines de septiembre de 1869. Pocos días antes, representantes del republicanismo manchego se habían reunido en Alcázar de San Juan para acordar las bases del Cantón Manchego ${ }^{89}$, con el que se dotaba de contenido regional al Pacto Federal Castellano, suscrito en junio del mismo año en Valladolid ${ }^{90}$. La manifestación, de este modo, formaba parte de la misma inercia organizativa y reivindicativa que habian inaugurado los pactos federales. A pesar de que acudieron militantes de diversos puntos de la provincia, la reunión terminó suspendiéndose ${ }^{91}$. El motivo, probablemente, tuvo que ver con el estallido de la rebelión republicana, alentada por las medidas restrictivas del gobierno.

En los meses siguientes, fueron los radicales y los carlistas quienes se movilizaron en las calles de Cuenca para afirmar su presencia sobre el espacio público. La causa esparterista, concebida como una monarquía electiva y transitoria hacia la república, estuvo estrechamente vinculada a la izquierda del progresismo y mostró una importante capacidad de arrastre entre la población conquense. La provincia de Cuenca, de hecho, registró el mayor número de exposiciones a las Cortes para elevar al trono al duque de la Victoria ${ }^{92}$. Entre la primavera y el verano de 1870, la campaña esparterista entró en su momento de mayor actividad. El 5 de junio, en Madrid, se celebró una multitudinaria manifestación que tuvo ecos en diversas provincias. En Cuenca, algunos "jóvenes ardientes $y$ entusiastas de aquella gloria nacional" se anticiparon a la convocatoria madrileña para organizar "tal solemne acto" a fines de mayo"

La reunión comenzó en la Fuente de San Francisco. Antes de la hora de la convocatoria "una numerosa concurrencia ocupaba los paseos inmediatos a la Glorieta". Era un sintoma de la popularidad que Espartero conservaba en la población, así como de la amplia repercusión que sobre el debate público tenía la

88 Sobre la cultura liberal, véase Alan S. Kahan, Liberalism in Nineteenth-Century Europe. The political culture of limited suffrage, Palgrave MacMillan, New York, 2003; Nicolas Roussellier, "La culture politique libérale", en Serge Berstein (dir.), Les cultures politiques en France, Éditions du Seuil, Paris, 2003, pp. 73-118; para el caso español, baste con citar el segundo volumen de la Historia de las Culturas Politicas en España y América Latina coordinado por María Cruz Romeo y Maria Sierra, La España Liberal, 1833-1874, Marcial Pons-Prensas de la Universidad de Zaragoza, Madrid, 2014.

89 La Igualdad, 3 y 7-9-1869.

90 Rafael Serrano García, "El federalismo castellano durante el Sexenio Revolucionario", Investigaciones Históricas: Época moderna y contemporánea, n ${ }^{\circ}$ 5, 1985, pp. 253-266.

91 La Esperanza, 24-9-1869.

92 Adrian Shubert, Espartero, el Pacificador, Galaxia Gutemberg, Madrid, 2018, p. 494.

93 El Eco de Cuenca, 1-6-1870. 
cuestión de la forma de gobierno. En ese contexto los radicales conquenses encontraron la oportunidad de mostrar su poder de convocatoria. De ello daba también cuenta "la profusión de banderas estandartes y gallardetes que con sus correspondientes lemas y versos alegóricos se veian desde los primeros momentos" de la manifestación. A pesar de que el Club Republicano celebraba sesión, fueron, de acuerdo a las fuentes, numerosos los militantes de esta agrupación que participaron en la reunión. Merece la pena reproducir la amplia descripción de la comitiva que recogió la prensa local:

"Eran las cinco y media, a cuya hora se hallaban formados los concurrentes en dos filas abiertas, y cada uno colocado en su puesto. Una elegante carretela tendida y dirigida por dos palafreneros conducía en primer término el retrato del ilustre patricio objeto de la ovación, engalanado con vistosas coronas de flores del mejor gusto, y en la parte posterior se veian dos jóvenes ondeando banderas moradas con el lema de Castilla por Espartero, que a la vez era escoltado por otros con banderas nacionales.

Al compás de los acordes sonidos de la música que tocaba el himno del héroe de Luchana, en medio de las demostraciones y vivas más entusiastas y de las repetidas detonaciones de los cohetes voladores que poblaban el aire, la carretela se colocó en el centro, y la comitiva emprendió su marcha por las calles de Madereros y de Palafox, subiendo por la de Cordoneros a la Plaza mayor, desde donde regresó por las de Solera, puerta de Valencia y de las Torres, al punto de partida, siendo aclamado en toda la carrera, no solo por los que formaban el séquito, sino también por otros hijos del pueblo que salian a su paso, recordando los hechos gloriosos de la vida militar del héroe".

La manifestación, sobre todo en su trayecto ascendente hasta la plaza Mayor, discurría por las calles donde se concentraban las clases acomodadas de la ciudad ${ }^{94}$. De los 115 individuos que aparecian censados como propietarios en el padrón municipal, al menos 66 residian en las vias que recorría la comitiva95, lo que significa que el $57 \%$ de los propietarios de Cuenca se concentraba en el $10 \%$ de las calles y plazas comprendidas en el padrón. El mismo cálculo podría realizarse respecto a los profesionales liberales (de los 58 censados como tales, 36 figuraban en esas mismas calles, el 60\%96); o los empleados (un 41\%97). Se entendía de manera implícita que el escenario adecuado para solemnizar una reunión pública era el área de residencia de las clases propietarias, de modo que se subrayaba, simultáneamente, una estratificación social del espacio de la politica. Lo más llamativo, en este sentido, es que el recorrido de la manifestación esparterista calcaba el de los desfiles procesionales.

94 Los cálculos que siguen se han realizado mediante un vaciado del Padrón Municipal de Cuenca del año 1872, AMCU, leg. 919, exp. 3.

9513 en Madereros, otros 13 en Juego de la Pelota, 5 en San Juan, 4 en Cordoneros, 18 en Correduría, 4 en la Plaza Mayor, 2 en la Puerta de Valencia y 7 en las Torres.

966 en Madereros, 4 en Juego de la Pelota, 7 en San Juan, 2 en Cordoneros, 13 en Correduría, 2 en la Plaza Mayor, 1 en Solera y 1 en las Torres.

9721 en Madereros, 8 en el Juego de la Pelota, 2 en Palafox, 15 en San Juan, 8 en Cordoneros, 20 en Correduría, 2 en la Plaza Mayor, 2 en Solera, 4 en la Puerta de Valencia y 9 en las Torres 
El trasvase entre los rituales tradicionales y otras formas modernas de llevar la política a la calle no debe sorprender. Fue, por el contrario, un fenómeno habitual en los procesos de politización durante la época liberal ${ }^{98}$. Era la primera vez que se celebraba una manifestación politica en Cuenca y los préstamos tomados de los desfiles religiosos eran evidentes, ya que era el modelo más inmediato y conocido para los organizadores. La elección de un recorrido que conectaba la Glorieta, centro de la sociabilidad cotidiana y espontánea de la ciudad, con el principal espacio simbólico del poder municipal (la plaza Mayor), a través de la Cuenca acomodada, podía parecer natural. Pero, además, el propio orden de la comitiva — con los participantes flanqueando en dos hileras la imagen de Espartero, objeto de veneración popular, y la banda de música al frenterecordaba más a las procesiones religiosas que a las aglomeraciones de manifestantes que en esos momentos se producian en numerosas ciudades de España.

El modelo de la manifestación esparterista de Cuenca fue imitado en otras localidades de la provincia en los días posteriores. Fue el caso de Villar del Saz de Arcas, una pequeña población próxima a la capital. Según la crónica, seguramente exagerada, de la prensa progresista, "casi todos [los] moradores" del pueblo, "sin distinción de clases, sexos ni edades, improvisando una orquesta, arcos de triunfo, banderas y estandartes", pasearon por sus calles "el retrato del insigne pacificador de España"99. La reunión terminó con una fiesta, de nuevo con elementos tradicionales como las hogueras y el baile público. Pocos días más tarde, también los liberales de Bólliga, otro pequeño municipio cercano a Cuenca, celebraron su manifestación esparterista ${ }^{100}$. Nuevas pautas de movilización politica, por tanto, comenzaban a asimilarse incluso en núcleos rurales de tamaño más reducido.

Los radicales de Cuenca, como se mencionó, mantuvieron su vocación esparterista incluso después de que las Cortes ratificaran la candidatura de Amadeo de Saboya. Lo que estaba claro es que, resuelta la cuestión monárquica, la imagen del duque de la Victoria había dejado de ser un factor de movilización operativo. Desde entonces, la propaganda radical se dirigió, sobre todo, a ensalzar la imagen de Ruiz Zorrilla, máximo dirigente del progresismo democrático a nivel nacional. En él se centraron las aspiraciones de completar un proyecto revolucionario que, a ojos de los radicales, habían dejado incompleto los gobiernos de la regencia. Incluso los poemas laudatorios que el periódico dedicó al rey, vinculaban a Amadeo I con el dirigente radical ${ }^{101}$. No es, por ello, extraño que el objetivo de la siguiente gran movilización promovida por los progresistas conquenses fuera protestar por la caída del gobierno de Ruiz Zorrilla en octubre de 1871.

98 Maurice Agulhon, La République au village, op. cit. p. 150 y ss.

99 El Eco de Cuenca 4-6-1870.

100 El Eco de Cuenca, 11-6-1870. Se planificaron actos similares "en Minglanilla y algunos otros pueblos de nuestra provincia", El Eco de Cuenca, 4-6-1870.

101 Es, en este sentido, ilustrativa la composición "A.S.M. el rey Amadeo I y al Excmo. Sr. Ministro de Fomento D. Manuel Ruiz Zorrilla", compuesta por el maestro Estanislao Martínez y publicada por El Eco de Cuenca, 11-3-1871: "Salve, Rey popular del pueblo ibero / esperanza del pobre y del hambriento / A ti y a tu ministro de Fomento / salve, repite, el Magisterio entero". 
La dimisión del gabinete radical, en efecto, provocó una oleada de movilizaciones de adhesión. En Madrid, el 4 de octubre, se celebró una multitudinaria manifestación bajo el lema “ „Viva el gobierno radical y disolución de Cortes!" 102. En Barcelona, Haro, Valencia, Toledo y Cuenca, los radicales también salieron a las calles ${ }^{103}$. En el caso de la capital conquense, parece que la convocatoria no fue tan concurrida como lo fue la manifestación esparterista, a pesar de que El Eco describiera al cortejo como "un inmenso gentio"104. Al contrario que en aquella ocasión, los progresistas aparecian ahora desunidos. Por otra parte, ni Ruiz Zorrilla ni Amadeo I tenian la capacidad de arrastre entre la militancia republicana que demostró la figura de Espartero.

Esta nueva manifestación mostraba algunas variantes respecto a la anterior. En primer lugar, hay constancia de que el comité radical anunció la reunión "por carteles con gran profusión en las calles"105, llamando a la participación de la ciudadanía:

"a las dos de la tarde de hoy 6 de Octubre de 1871 se celebrará en esta ciudad una manifestación pacífica en favor de la politica radical de moralidad, justicia y economías practicada por el ministerio presidido por el eminente hombre politico Ruiz Zorrilla.

Se invita a las personas que quisieran asociarse a este acto de verdadera adhesión a la politica radical del Gabinete dimisionario.

La reunión tendrá lugar en los paseos de la arboleda de San Francisco"106.

El comité radical ocupaba la cabeza de una reunión que, en esta ocasión, había roto el orden casi procesional de la manifestación esparterista. Con ellos desfilaba, de acuerdo a la burlona crónica que recogió La Esperanza, "una murga o música de la Milicia voluntaria, tocando el correspondiente Himno de Riego"107. Varias banderas con los colores nacionales llevaban inscritos las consignas que resumian el programa radical: "Constitución de 1869. Amadeo I. Politica radical. Moralidad. Justicia. Economías"108. La prelación de los anteriores lemas era elocuente: la figura del rey estaba subordinaba a la Constitución democrática. E1 trayecto, por lo demás, sólo se apartaba del anterior recorrido en un punto: en vez de descender desde la Plaza Mayor por la calle Solera, lo hacía por la de Caballeros, en la que se ubicaba el Círculo Popular de los radicales.

102 Eduardo Higueras Castañeda, Con los Borbones, jamás. Biografía de Manuel Ruiz Zorrilla (1833-1895), Marcial Pons, Madrid, 2016, p. 216.

103 La Nación, 12-10-1871.

104 El Eco de Cuenca, 11-10-1871. Un remitente anónimo remitió al periódico carlista La Esperanza (12-10-1871, una desdeñosa reseña sobre la manifestación, en la que se describía a los participantes como "unos veinte o treinta progresistas, acompañados de otros tantos quintos $y$ chiquillos".

105 La Esperanza, 12-10-1871.

106 El Eco de Cuenca, 11-10-1871.

107 La Esperanza, 12-10-1871.

108 El Eco de Cuenca, 11-10-1871. 
La presión en las calles no bastó para que el monarca extendiera a Ruiz Zorrilla el decreto de disolución de las Cortes y el encargo de convocar elecciones. Por el contrario, las tres crisis de gobierno que se sucedieron en los meses siguientes fueron resueltas, ante la exasperación radical, en sentido conservador. Hasta junio de 1872, cuando Amadeo I llamó de nuevo a Ruiz Zorrilla a formar gobierno, el tibio dinastismo de los radicales se enfrió. En determinados momentos, rozó la hostilidad. Lejos de ser un giro repentino, los radicales habían mostrado una cierta inclinación hacia la república unitaria, que contemplaban como un fin a corto o medio plazo al menos desde 1870. A comienzos de 1873 la opción republicana aparecía como la mejor manera de sortear la presión conservadora, que hacía peligrar el programa reformista de Ruiz Zorrilla109.

Fue, precisamente, en el Círculo Popular donde los radicales y los federales conquenses se reunieron para escenificar su unión tras la proclamación de la República ${ }^{110}$. El acuerdo se ratificó semanas más tarde con una nueva manifestación ${ }^{111}$. No era la primera muestra de afinidad entre los republicanos y progresistas de Cuenca. A pesar de los ocasionales desencuentros, la tendencia a la colaboración había sido una constante ${ }^{112}$. Sin duda, la fuerte competencia que representaban los sectores ultracatólicos favoreció su convergencia. De este modo, la movilización carlista, especialmente intensa en 1871, fue un factor crucial en la radicalización de los progresista-demócratas y su definitivo abandono de la causa monárquica.

\section{MARGARITAS Y PROCESIONES: LA MOVILIZACIÓN CARLISTA}

El clero catedralicio, con el obispo al frente, tuvo un papel preponderante en la movilización contrarrevolucionaria en Cuenca. El palacio episcopal y el cabildo dieron cobertura tanto a la prensa carlista local como al desarrollo de la Comunión Católico-Monárquica. En diferentes convocatorias electorales, el propio obispo y el canónigo lectoral encabezaron las candidaturas de esta agrupación. Sin embargo, la adhesión del alto clero conquense a la causa carlista se movió en una cierta ambigüedad. De hecho, la opinión pública atribuía al prelado preferencias alfonsinas ${ }^{113}$. El movimiento carlista, en cualquier caso, ofrecía la mejor oportunidad para defender el integrismo católico en el terreno legal ${ }^{114}$. De acuerdo al relato del Vizconde de la Esperanza:

"cuando las elecciones [de 1869] se le presentaron [al obispo] algunos legitimistas en Cuenca, y le dijeron:

109 Eduardo Higueras Castañeda, Con los Borbones, jamás. Biografia de Manuel Ruiz Zorrilla, 1833-1895, op. cit. pp. 273 y ss.

110 El Eco de Cuenca, 29-3-1873.

111 La Discusión, 26-4-1873.

112 Eduardo Higueras Castañeda, "Radicales y federales: el ejemplo de Cuenca en el proceso democratizador de 1868-1873", op. cit.

${ }^{113}$ El Eco de Cuenca, 23-12-1871.

114 "Como la nobleza y la burguesía moderada, la Iglesia sólo volvió francamente los ojos hacia el carlismo en 1868, cuando lo reputó como el más eficaz antídoto contra la revolución”, escriben Julio Aróstegui, Jordi Canal y Eduardo González Calleja, Las guerras carlistas, op. cit. p. 151. 
Señor, se trata de nuestra santa religión; necesitamos vuestro nombre para llevarlo a las urnas.

Tomadlo; id en buena hora, y Dios os ilumine; contestó"115.

Las conexiones entre el obispo y el carlismo son evidentes. Era, por otra parte, lógico que el prelado dejara la cuestión dinástica en un segundo plano o que, directamente, la silenciara. El propio pretendiente aceptaba la subordinación del adjetivo monárquico a los principios religiosos ${ }^{116}$. Fue, por ello, la causa ultracatólica la que actuó como un factor cohesivo y movilizador crucial para las familias contrarrevolucionarias, ante el desafio secularizador de la monarquía democrática. Esto no significa que el elemento legitimista careciera de empuje entre los sectores antiliberales conquenses. Pero, más que el pleito dinástico del pretendiente carlista, fue la legitimidad de Pío IX, el "prisionero del Vaticano", la causa que esgrimieron frente a la monarquía de Amadeo I, el hijo del "carcelero del Papa". Por supuesto, a nadie se le escapaba que la defensa del poder temporal del pontífice y el legitimismo carlista iban, en aquel contexto, de la mano, aunque Pío IX hubiera negado su apoyo explícito al pretendiente ${ }^{117}$.

Desde mediados de 1869, la presencia de un importante sustrato antiliberal en Cuenca era evidente. Así lo indica la aparición de periódicos como La Juventud Católica y La Honda de David ${ }^{118}$. Su impacto, sin embargo, apenas fue perceptible en el terreno electoral o por la vía insurreccional. La incidencia de la rebelión carlista del verano de 1869, a pesar de que la Mancha fue uno de sus principales escenarios"119, fue minima: "en la provincia de Cuenca hay mucho carlista - aseguraba El Eco-, pero casi podemos asegurar que no es gente de armas"120. A partir de la primavera de 1870, sin embargo, puede observarse un notable incremento de la actividad carlista. A ello contribuyó la reorganización de la Comunión Católico Monárquica. Tras la celebración de la junta de Vevey, los sectores provenientes del neocatolicismo ganaron peso en la dirección del partido.

Los carlistas conquenses publicaron un escrito de adhesión a los acuerdos de Vevey. Lo acompañaban ciento cincuenta firmas ${ }^{121}$. Entre ellas, como hacia notar El Eco de Cuenca, figuraban las de "muchos de los que [habían] servido y comido del presupuesto de gobiernos representativos de la exreina doña Isabel" ${ }^{122}$.

115 Vizconde de la Esperanza, La Bandera Carlista en 1871. Historia del desarrollo y organización del Partido Carlista desde la Revolución de Septiembre, Madrid, Imprenta de El Pensamiento Español, 1871, p. 241.

116 Begoña Urigüen, Origenes y evolución de la derecha española, op. cit. p. 309.

117 Sobre la utilización del catolicismo como fuente de legitimidad por el pretendiente carlista, y el "trasvase de autoridad" del mismo a "otros sujetos de legitimidad", como Pio IX, argumenta Lluís Ferran Toledano González, "El crucifijo y el baile”, op. cit. pp. 79-197.

118 Ángel Luis López Villaverde e Isidro Sánchez Sánchez, Historia y evolución de la prensa conquense (1811-1939), UCLM, Cuenca, p. 173.

119 Manuela Asensio Rubio, El carlismo en Castilla-La Mancha (1833-1875), Almud, Toledo, 2011.

120 El Eco de Cuenca, 28-7-1869.

121 La Esperanza, 10-5-1870, La Regeneración, 11-5-1870.

122 El Eco de Cuenca, 18-5-1870. 
Dos antiguos regidores, de hecho, se integraron en la junta Católico-Monárquica provincial elegida a comienzos de $1871^{123}$. Se trataba, como ya se ha explicado, de la culminación de un proceso de convergencia que había comenzado en los años anteriores a la Gloriosa. La oposición al reconocimiento del reino de Italia aceleró la conformación de esa "amalgama contrarrevolucionaria"124. Debe reiterarse que Cuenca había sido un feudo neocatólico entre 1865 y 1868. Las redes de influencia tejidas por Severo Catalina y el obispo de la diócesis fueron fundamentales a la hora de apuntalar ese dominio. Catalina, en algún momento que no es posible precisar, pero que pudo coincidir con la abdicación de Isabel II en su hijo en junio de 1870, manifestó su adhesión al pretendiente, tal y como el propio Carlos VII anotó en su diario ${ }^{125}$.

De este modo, podría interpretarse que las clientelas que habían apuntalado el dominio neocatólico en Cuenca pasaron a reforzar las filas carlistas desde mediados de 1870. A ello debe sumarse el importante incremento de la popularidad de Miguel Payá en torno a las mismas fechas. Desde finales de 1869, el obispo de Cuenca participó en el Concilio Vaticano I. Sus intervenciones fueron seguidas con atención por la prensa Católico-Monárquica. Fue, sobre todo, su discurso en defensa de la infalibilidad pontificia, en julio de 1870, publicado por iniciativa del propio Pío IX, el que le valió su mayor cota de prestigio ${ }^{126}$. En octubre, el Concilio fue suspendido por la entrada de las tropas de Víctor Manuel II en Roma. Su regreso a Cuenca, a comienzos de ese mes, dio lugar a algunas muestras de adhesión ${ }^{127}$.

La imagen de una iglesia perseguida por el liberalismo, de este modo, se veía reforzada y, a la vez, quedaba reducida a una imagen maniquea: la del "Paparey", Pío IX, representante de la civilización cristiana amenazada por la revolución que encarnaba el monarca italiano. Todo ello significaba un refuerzo para las reivindicaciones ultramonárquicas en España, justo en el momento en el que la candidatura al trono del hijo de Víctor Manuel entraba en su momento decisivo. En Cuenca, a fines de noviembre, aparecieron "algunos pasquines contra el duque de Aosta y diputados que le han dado su sufragio" cuya autoría se atribuyeron los carlistas $^{128}$.

A pesar de que la candidatura de Miguel Payá por la circunscripción de Huete fracasó en las elecciones a Cortes de marzo de 1871, el obispo obtuvo un acta de senador por la provincia de Guipúzcoa dentro de una candidatura carlista. Su elección se festejó entre los tradicionalistas conquenses como un triunfo propio: "todo lo más selecto y católico de la población se apresuraron a manifestar una vez más su amor al héroe de Concilio Vaticano, y su adhesión a los principios simbolizados en el sagrado lema de Dios, Patria y Rey"129. El obispo

123 La Esperanza, 4-2-1871.

124 Julio Aróstegui, Jordi Canal, Eduardo González Calleja, Las guerras carlistas, op. cit. p. 78.

125 "Severo Catalina, aunque no públicamente, dice que está con nosotros y consulta con Aparisi su manifiesto", apud Begoña Urigüen, Orígenes y evolución de la derecha española, op. cit. p. 384.

126 Pilar Tormo Martín de Vidales, El Cardenal Payá, apuntes para una biografía, Estudio Teológico de San Ildefonso, Toledo, 1992, pp. 37-39.

127 El Pensamiento Español, 10-10-1870.

128 La Esperanza, 22-11-1870.

129 La Regeneración, 1-4-1871. 
alcanzó, de este modo, un altavoz parlamentario que la prensa carlista contribuyó a amplificar ${ }^{130}$. En Cuenca, en esos momentos, comenzaron a publicarse dos nuevas cabeceras ligadas al mismo sector de opinión. La Bandera Nacional, dirigida por el secretario del comité carlista y La Verdad, suplemento del Boletín Diocesano ${ }^{131}$. Todo ello ayuda a explicar la intensidad de las movilizaciones contrarrevolucionarias en Cuenca a mediados de 1871.

El regreso del prelado a Cuenca tras la suspensión de las sesiones del Senado sirvió de pretexto a la Juventud Católica para organizar un acto público de adhesión a los principios tradicionalistas. "Unos diez o doce carruajes" con representantes de la Junta Católico-Monárquica, del clero parroquial y del cabildo salieron a su encuentro en las inmediaciones de la ciudad. De acuerdo a la crónica que publicó el Boletín Eclesiástico, a la entrada de la comitiva, "la ciudad toda se puso en movimiento, y las gentes corrian, $y$ las campanas y los cohetes aumentaban [...] el entusiasmo". Puede que no fuera "toda la ciudad" la que salió a recibir al obispo, pero lo cierto es que incluso El Eco de Cuenca, en tono desdeñoso, reconoció que "nada faltó para demostrar el júbilo que una parte de esta dócil población sentía al ver de regreso al prelado, después de sus fatigas parlamentarias"132.

No se trataba solamente, por supuesto, de dar la bienvenida al obispo, sino de hacer una verdadera demostración de fuerza en sentido contrarrevolucionario. Se homenajeaba al prelado como dignidad religiosa, pero también al senador por la Comunión Católico-Monárquica:

"Los balcones se hallaban engalanados con preciosas colgaduras; las calles alfombradas con los ramos y flores que se arrojaban al pasar su excelencia ilustrisima, volando además por el aire papeletas impresas que se arrojaban con las flores, en las cuales se leian vivas y vitores a la Religión católica apostólica romana, al inmortal Pio IX, Papa-Rey, a España, nación católica por excelencia, al héroe del Concilio y ya célebre senador por Guipúzcoa, nuestro Excmo. Prelado, y al Papa libre, y al Papa-Rey"133.

La comitiva inició la subida a la Catedral por las calles principales de la ciudad intramuros, desde Palafox hasta la Plaza Mayor. Allí, según la carta que un dirigente carlista local remitió a La Regeneración, le esperaban "3000 personas, que llenaron la catedral mientras se cantó el Te Deum". A su paso, cruzaron un arco de triunfo "de ramas y follaje, adornado con flores y coronas". Otro más se había colocado en la entrada del palacio episcopal, donde los seminaristas le cantaron un himno compuesto para la ocasión por el presidente

130 Sus intervenciones fueron divulgadas por una imprenta conquense vinculada a posiciones clericales: El señor Obispo de Cuenca en el Senado, Imprenta de Francisco Gómez e hijo, Cuenca, 1871. La misma imprenta publicó también su discurso sobre la infalibilidad pontificia: Miguel Payá y Rico, Discurso pronunciado en la octogésima congregación general del Concilio Ecuménico Vaticano en pro de la infalibilidad pontificia el dia $1^{\circ}$ de julio de 1870 , Imprenta de Francisco Gómez e hijo, Cuenca, 1873.

131 Ángel Luis López Villaverde e Isidro Sánchez Sánchez, Historia y evolución de la prensa conquense (1811-1939), op. cit., pp. 176-177.

132 El Eco de Cuenca, 3-6-1871.

133 La Esperanza, 14-6-1871. 
de la Juventud Católica, Pascual Carrascosa, que también fue repartido entre la población. Noches más tarde, se ofreció al obispo una serenata y numerosas casas iluminaron los balcones. Un profesor de química del seminario "iluminó también periódicamente la plazuela de Palacio con la luz de magnesio, que brillaba extraordinariamente y oscurecia las otras luces". El Boletín Eclesiástico y la prensa carlista no dudaron en calificar los festejos como una "victoria en toda la línea" 134 .

Ese mismo día se había celebrado la procesión del Corpus. De nuevo, la tradición religiosa sirvió de cauce para la reivindicación política. Tal y como denunciaron los progresistas conquenses, "los carlistas, en su afán de convertirlo todo en sustancia, hasta en las cruces parroquiales llevaban sus correspondientes margaritas"135. El desfile religioso, de este modo, se convertía en un acto público de reivindicación legitimista ${ }^{136}$. Las procesiones, en efecto, eran una forma de proyectar los principios politicos sobre la calle que se acomodaban especialmente bien a la cultura tradicionalista. Era su forma natural de manifestarse. Por las palabras de El Eco de Cuenca, podía inferirse que no era la primera vez que las inevitables margaritas habían decorado los estandartes y cruces de las parroquias. Para los radicales, era "una inconveniencia" convertir en política las celebraciones religiosas. Sobre todo, porque les obligaba a retraerse de ellas ${ }^{137}$.

Los festejos por la llegada del Obispo y la procesión del Corpus se encadenaron con la preparación del jubileo por el 25 aniversario del reinado de Pío IX, programado para el día 16 de junio. La iniciativa partió de la Asociación de Católicos y tuvo alcance nacional ${ }^{138}$. En Cuenca, fue la Juventud Católica la encargada de organizar la conmemoración con un programa que seguía el esquema del recibimiento al obispo: colgaduras, iluminación de balcones, función religiosa, procesión, música, reparto de pan, etcétera. La caridad, en esta ocasión, se realizó de forma selectiva de acuerdo a criterios partidarios. Según denunció El Eco de Cuenca, antes del reparto "se [verificó] previamente y casa-hita una información verbal sobre cuál era la opinión politica del interrogado. Si carlista, recibia pan, si liberal, no se lo daban"139. Para los radicales, las últimas demostraciones clericales habían sido monopolizadas por la Comunión CatólicoMonárquica:

"Al recordar el recibimiento politico que hicieron no ha muchos dias al Prelado [...] lo que se proyecta es una manifestación politica, velada por el crespón religioso: manifestación que tendrá lugar en todas o casi todas las provincias a la vez, según las órdenes que han circulado ad hoc"140.

\footnotetext{
134 La Regeneración, 5-6-1871.

135 El Eco de Cuenca, 14-6-1871.

136 Subraya la relevancia de "l'intrusion de forts symboles idéologiques dans les rituels collectifs de la communauté, de la famille et de la vie religieuse", como canal de politización, Peter MacPhee, "Contours nationaux et régionaux de l'associationnisme politique en France (1830-1880)", en La politisation des campagnes au XIXe Siècle, op. cit. pp. 207-219, p. 214.
}

137 El Eco de Cuenca, 24-6-1871.

138 Begoña Urigüen, Origenes y evolución de la derecha española, op cit. pp. 361-362.

139 El Eco de Cuenca 21-6-1871.

140 El Eco de Cuenca, 14-6-1871. 
A juicio de $E l E c o$, esas órdenes partían directamente del pretendiente carlista. Los actos programados, por ello, se interpretaron como un desafio al cual los radicales trataron de responder. Al igual que ocurrió con las procesiones de Madrid y otras ciudades, en la capital conquense se produjeron disturbios: "en Cuenca, las funciones hubieran sido lucidisimas, a no ser por los desmanes a que se entregaron unos cuantos progresistas y demócratas", denunciaba La Esperanza. De acuerdo a su relato, al empezar la iluminación "unos sesenta [progresistas] con la música de voluntarios a la cabeza, y tocando la Marsellesa y el himno de Garibaldi, fueron a la Plaza Mayor, y alli empezaron sus actos vandálicos" ${ }^{141 .}$ Conforme a otras fuentes, también de orientación carlista, la banda de la Milicia no llegó a salir a la calle. Simplemente programaron a la misma hora su ensayo, en el que tocaron intencionadamente los himnos de Riego, de Garibaldi "y a eso de las diez y cuarto la Marsellesa, habiéndose ya oido algunos vivas a diferentes cosas y personas y a la república roja"142.

Estos últimos gritos, si realmente se dieron, dificilmente podrian haber sido proferidos por un progresista. Aludian, por supuesto, a los episodios anticlericales de la Comuna de París. En todo caso, debe subrayarse el hecho de que la fuerza ciudadana, comandada por dirigentes del Partido Radical, interpretara himnos relacionados con el universo simbólico del federalismo, como el himno de Garibaldi o la Marsellesa. Se trata de un indicio del desplazamiento hacia el republicanismo de las bases progresista-demócratas. Un giro que no implicaba únicamente la preferencia por una forma de gobierno u otra, sino una radicalización de sus convicciones políticas. Por eso, a fines de junio, El Eco defendía la necesidad de que el gobierno prohibiera el "culto externo de toda religión, pues es sabido que desde el momento en que estos actos se hacen extensivos a las calles y plazas de las poblaciones, se desnaturalizan"143.

No se trataba de limitar el derecho de reunión, sino de forzar la separación entre religión y política. Pero, en todo caso, era una demanda que claramente iba un paso más allá del catolicismo liberal que había caracterizado al progresismodemocrático ${ }^{144}$. Ese avance en sentido laicista del radicalismo era la respuesta al empuje que estaba demostrando el carlismo en la calle. Un desafio que no terminó con los disturbios del 16 de junio. Por el contrario, pocos días más tarde "aparecieron en las esquinas algunos pasquines" con los siguientes lemas: "Guerra sin tregua a los liberales asta suesterminio. Viba el catolicismo. Muera la libertad", y "Viba Carlos $7^{\circ}$ Rey de España. Viba Pio $9^{\circ}$ Rey de Roma. Abajo los herejes"145. Algunos radicales, al parecer, recibieron anónimos amenazantes.

141 La Esperanza, 22-6-1871. Esos actos vandálicos, en los que coinciden todas las fuentes, se concretaron en la destrucción de los arcos florales, y algunas pedradas y disparos contra los balcones iluminados, incluida la fachada del palacio episcopal (algunos disparos, al parecer, se hicieron para amedrentar al mayordomo del obispo).

142 El Pensamiento Español, 21-6-1871.

143 El Eco de Cuenca, 24-6-1871. Considera, en este sentido, Gregorio Alonso que "la implicación del clero en politica, y no tanto la defensa de la libertad de conciencia de los ciudadanos, era el motor del anticlericalismo patrio", La nación en capilla, op. cit. p. 313.

144 Gregorio Alonso, La nación en capilla, op. cit. pp. 308-316.

145 El Eco de Cuenca, 21-6-1871. 
A pesar de que la tensión politica parecía apuntar a un desenlace violento, la confrontación entre carlistas y radicales se resolvió de manera pacífica, en las urnas. Ya se ha hecho referencia a la victoria de los primeros en las elecciones municipales de diciembre de 1871. En ellas, unos y otros demostraron una importante capacidad de movilización. En abril de 1872, ante la convocatoria de unas nuevas elecciones a Cortes, tuvieron la ocasión de confirmarlo, aunque esta vez lo hicieron mediante una artificiosa coalición antigubernamental. Era el resultado del pacto de Unión Nacional que habian alcanzado las oposiciones al gobierno de Sagasta. Radicales, carlistas y republicanos quedaban vinculados en una alianza defensiva que trataba de contrarrestar la previsible presión del gobierno sobre el cuerpo electoral. El pacto, en Cuenca, resultó un éxito. El candidato carlista Manuel García Rodrigo, yerno de Cándido Nocedal, salió vencedor ${ }^{146}$. No llegó, sin embargo, a recoger su acta: la insurrección carlista, decretada por el pretendiente, puso fin a la estrategia legal que representaba la Comunión Católico-Monárquica.

\section{CONCLUSIONES}

Desde el estallido de la insurrección carlista en abril de 1872 es dificil encontrar nuevas demostraciones públicas del arraigo de la Comunión Católico Monárquica había adquirido en Cuenca. Esa desmovilización está relacionada, de un lado, de la "desestructuración de la red de juntas, prensa y contactos carlistas" 147 que el abandono de la vía legal había provocado y, de otro, por las medidas adoptadas por el gobierno para expulsar a sus militantes de la esfera pública. La siguiente irrupción del carlismo en la ciudad convirtió a sus calles en escenario de la lucha militar. En octubre de 1873, el cabecilla Santés entró por sorpresa en Cuenca. Un centenar de conquenses - entre ellos algunos seminaristas-, se unieron a la facción. Un año más tarde, en julio, el saqueo de la ciudad por las tropas de Alfonso Carlos de Borbón, resultó mucho más sangriento.

En la medida en que el asalto fue protagonizado por una fuerza que provenía del exterior de la propia ciudad, no debe interpretare como el resultado lógico de la tensión entre demócratas y católico-monárquicos vivida en los años anteriores. Sin embargo, el apoyo del carlismo local en los ataques fue sensible, aunque por lo general se manifestara de manera pasiva. Asi lo sugería el republicano Santiago López en su crónica sobre "los sucesos de Cuenca":

"Gran parte de su vecindario es afecto, por ese extraño maridaje de la religión y la politica, a la bandera de D. Carlos.

¿Qué extraño es, dadas estas simpatias, que los muchos partidarios del carlismo recibieran con júbilo no disimulado y con alborozo mal contenido, la noticia de que numerosas fuerzas facciosas se dirigian a poner sitio a la ciudad?"148.

Se abortaba, de este modo, un proceso de politización en el que los propios

146 AMCU, leg. 625, exp. 10.

147 Jordi Canal, El carlismo, op. cit. p. 174.

148 Santiago López, Los sucesos de Cuenca ocurridos en julio de 1874, Imprenta y librería de Manuel Mariana y Sanz, Cuenca, 1878, p. 27. 
carlistas habían jugado un papel protagonista. A pesar de los episodios esporádicos de violencia, centrados, sobre todo, en el terreno simbólico, ese proceso apuntaba a una pacificación de las luchas ideológicas ${ }^{149}$. La elevada tensión política que experimentó la ciudad se encauzó de manera eficaz por las vías legales. El componente insurreccionalista del carlismo estuvo ausente hasta 1873. Durante los años del reinado de Amadeo I, a la vez que republicanos y radicales promovian la socialización de los valores democráticos, los sectores ultramonárquicos hicieron del marco legal un terreno neutro sobre el que desplegar la acción politica y propagar los principios tradicionalistas. La causa de la monarquía democrática - sobre todo en su concreción esparterista-, y del legitimismo - más animado por las reivindicaciones de Pío IX que por las del pretendiente carlista-, actuaron, en este sentido, como eficaces elementos de movilización y encuadramiento entre distintos sectores sociales.

Esa pugna, en la escala local, mostró el equilibrio de fuerzas entre los sectores favorables a la secularización del espacio público y los que, bajo la cobertura clerical, apoyaron el integrismo católico. La apertura del marco político habia permitido que formas tradicionales de acción colectiva - las serenatas, la iluminación o las colgaduras, por ejemplo - se integraran en campañas políticas de alcance nacional, a la vez que aparecían otras formas modernas de ocupar el espacio público, como la manifestación ${ }^{150}$. El asalto carlista, en este sentido, significó una cesura determinante. El movimiento democrático, que había mostrado un considerable vigor en la ciudad, quedó desarticulado. A ello contribuyó la restauración de la monarquía a fines de 1874. Desde entonces, la única muestra reseñable de actividad democrática en la calle fue, precisamente, la procesión cívica que, desde 1877, se institucionalizó como recuerdo a las víctimas del saqueo carlista de Cuenca ${ }^{151}$.

Enviado el (Submission Date): 12/03/2019

Aceptado el (Acceptance Date): 5/05/2019

149 "On peut [...] considérer la politisation [...] comme une pacification (modernité morale) donc comme une alternative à la violence", explica Maurice Agulhon, "Présentation", en La politisation des campagnes au XIXe Siècle, op. cit. p. 9.

150 Esa simultaneidad entre las "formas de acción colectiva heredadas del pasado", y la aparición de "un nuevo repertorio [...] más cosmopolita que local; más autónomo que dependiente de acontecimientos o de rituales heredados; [y] más modular que específico", fue una constante en la modernización de la acción política, como indica Sidney G. Tarrow, El poder en movimiento, op. cit. p. 98.

151 Herminio Lebrero Izquierdo, Lugares de Memoria Institucionalizada en Cuenca (1877-2017), op. cit. pp. 64-70. 